\title{
Functional Recovery of Anterior Semicircular Canal Afferents following Hair Cell Regeneration in Birds
}

\author{
Richard Boyle, ${ }^{1,4}$ Stephen M. Highstein, ${ }^{2}$ John P. Carey, ${ }^{3}$ and Jinping Xu ${ }^{4}$ \\ ${ }^{1}$ Ames Research Center, National Aeronautics and Space Administration, Moffett Field, CA 94035, USA \\ ${ }^{2}$ Department of Otolaryngology and Department of Neurobiology, Washington University, St. Louis, MO 63110, USA \\ ${ }^{3}$ Department of Otolaryngology/Head and Neck Surgery, Virginia Merrill Bloedel Hearing Research Center, \\ University of Washington, Seattle, WA 98195, USA \\ ${ }^{4}$ Department of Otolaryngology/Head-Neck Surgery and Department of Physiology and Pharmacology, Oregon Health Sciences \\ University, Portland, OR 97201, USA
}

Received: 17 April 2001; Accepted: 14 August 2001; Online publication: 6 November 2001

\begin{abstract}
Streptomycin sulfate $(1.2 \mathrm{~g} / \mathrm{kg}$ i.m.) was administered for 5 consecutive days to 5-7-day-old white Leghorn chicks; this causes damage to semicircular canal hair cells that ultimately regenerate to reform the sensory epithelium. During the recovery period, electrophysiological recordings were taken sequentially from anterior semicircular canal primary afferents using an indentation stimulus of the canal that has been shown to mimic rotational stimulation. Chicks were assigned to an early (14-18 days; $n=8)$, intermediate (28-34 days; $n=5)$, and late (38-58 days; $n=4)$ period based on days after treatment. Seven untreated chicks, 15-67 days old, provided control data. An absence of background and indent-induced discharge was the prominent feature of afferents in the early period: only "silent" afferents were encountered in 5/8 experiments. In several of these chicks, fascicles of afferent fibers were seen extending up to the epithelium that was void of hair cells, and intra- and extracellular biocytin labeling revealed afferent processes penetrating into the supporting cell layer of the crista. In $3 / 8$ chicks 74 afferents could be characterized, and they significantly differed from controls $(n=130)$ by having a lower discharge rate and a negligible response to canal stimulation. In the intermediate period there was considerable variability in discharge properties of
\end{abstract}

Correspondence to: Dr. Richard Boyle $\bullet$ M/S 239-11 • NASA $・$ Moffett Field, CA 94035-1000. Telephone: (650) 604-1099; fax: (650) 6043954; email: rboyle@mail.arc.nasa.gov
121 afferents, but as a whole the number of "silent" fibers in the canal nerve diminished, the background rate increased, and a response to canal stimulation detected. Individually biocytin-labeled afferents had normal-appearing terminal specializations in the sensory epithelium by 28 days poststreptomycin. In the late period, afferents $(n=58)$ remained significantly different from controls in background discharge properties and response gain. The evidence suggests that a considerable amount of variability exists between chicks in the return of vestibular afferent function following ototoxic injury and that the secretory function of regenerating hair cells might become functional before their transducer function.

Keywords: vestibular, streptomycin, electrophysiology, biocytin, semicircular canal

\section{INTRODUCTION}

Anatomical studies have firmly established that avian auditory and vestibular hair cells can regenerate following acoustic trauma or ototoxic levels of administered aminoglycoside antibiotics (Cotanche 1987a; Cruz et al. 1987; Corwin and Cotanche 1988; Ryals and Rubel 1988; Lippe et al. 1991; Rubel et al. 1991; Weisleder and Rubel 1993; Cotanche et al. 1994; Kil et al. 1997). It is believed that damaged cells are initially extruded from the neuroepithelium and replaced by 
new hair cells. Regenerated hair cells could arise via a number of possible mechanisms. These include supporting cell proliferation, with some daughter cell progeny differentiating into hair cells (indirect transdifferentiation; Corwin and Cotanche 1988; Ryals and Rubel 1988; Raphael et al. 1994); supporting cells might also directly convert into hair cells without undergoing cell division (direct transdifferentiation; Baird et al. 1996; Roberson et al. 1996; Steyger et al. 1997). Another possible source is undifferentiated stem cells that continuously re-enter the cell cycle to produce new hair cells (Jorgensen and Mathiesen 1988; Roberson et al. 1992). To complete the structural regeneration, new hair bundles are formed (Cotanche 1987a) and afferent and efferent synaptic contacts are established (Duckert and Rubel 1993; Ryals and Westbrook 1994; Blumberg et al. 1997; Henning and Cotanche 1998).

Behavioral, anatomical, and electrophysiological data indicate that both auditory (Cotanche 1987b; Adler et al. 1993; Niemiec et al. 1994; Salvi et al. 1994; Poje et al. 1995; Chen et al. 1996; Müller et al. 1996) and vestibular (Jones and Nelson 1992; Carey et al. 1996; Masetto and Correia 1997a,b; Li and Correia 1998; Goode et al. 1999) functions recover following hair cell regeneration in birds. Avian vestibular organs, like those of mammals (Ades and Engström 1965), possess two hair cell populations - the type I cell innervated by the afferent calyx and the type II cell that is contacted by afferent boutons (Smith 1985). Weisleder et al. (1995) studied the time course of hair cell regeneration in the anterior semicircular canal following ototoxic damage and found that the afferent calyx returns after the epithelium is repopulated with hair cells. The response dynamics of the primary afferents might reflect this outcome as their input/output functions are related to the manner and types of hair cells that they contact (Fernández et al. 1988, 1995; Lysakowski et al. 1995; Lysakowski and Goldberg 1997). Instead we found an interesting sequence of afferent recovery: the background firing of afferents recovered before any evoked response was seen. This may have been due to a differential recovery of the secretory and transduction processes of the hair cells or to some pathological cause of action potential discharge in primary afferents. Our data are suggestive of the former possibility. A preliminary report has been published (Boyle et al. 1994).

\section{METHOD}

\section{Subjects}

Streptomycin sulfate (Sigma) in normal saline (1.2 $\mathrm{g} / \mathrm{kg}$ i.m.) was administered for 5 consecutive days to 5-7-day-old white Leghorn chicks (Gallus domesticus.) This protocol induces an aminoglycoside ototoxicity that can destroy up to $83 \%$ of the hair cells in the chick semicircular canal crista (Weisleder and Rubel 1993). Several chicks in this report also participated in the study of Carey et al. (1996), and more details of animal behavior, husbandry, eye movement measurement, and horizontal vestibulo-ocular reflex (VOR) testing and analysis can be found there. After drug administration, the surviving and control animals were transported from Seattle to the Animal Care Facilities at the Oregon Health Sciences University. All procedures were performed in accordance with the American Physiological Society Animal Care Guidelines and were approved by the Institutional Animal Care and Use Committees at the Oregon Health Sciences University and the University of Washington.

\section{Experimental paradigm and data collection}

Animals were anesthetized with an intramuscular (i.m.) injection of $45 \mathrm{mg}$ ketamine and $2.2 \mathrm{mg}$ xylazine per cc; supplemental doses were regularly given at 30 minute intervals or as needed. Rectal temperature was maintained at $\sim 42^{\circ} \mathrm{C}$ using a servo-controlled heating pad and a heat lamp. The skull was exposed and a bolt was attached to the dorsal surface at the midline using dental cement and miniature self-tapping screws (Morris Precision). The head was secured by coupling the bolt to a vibration isolation table, with the head oriented to permit access to the middle ear space via a retroauricular approach through the mastoid process. To minimize the amount of surgical manipulation in the young, experimental chicks, we selected the anterior, not the horizontal, semicircular canal afferents for study. A small portion $(\sim 2-3 \mathrm{~mm})$ of the osseous anterior canal was removed to expose the membranous duct and allow mechanical stimulation of the canal limb. The bone over the anterior canal nerve was sufficiently removed to expose the nerve for recordings.

Angular head acceleration was mimicked using mechanical indentation of the anterior canal limb (Dickman et al. 1988; Dickman and Correia 1989a; Boyle and Highstein 1991; Rabbitt et al. 1995). An indenter fashioned from a $1.2 \mathrm{~mm}$ glass rod tapered at one end, fire-polished to a diameter of $\sim 500 \mu \mathrm{m}$, and tipped with a malleable substance (takiwax; Cenco) was fitted to a piezoelectric microactuator (Burleigh PZL-100) placed in-line with a linear variable differential transducer (Schaevitz DEC-050) to obtain its instantaneous position. The piezo was driven through a high-voltage amplifier (Trig-Tek 207A) using a digital waveform generator (Tektronics FG5010). The tapered end of the indenter was positioned perpendicular to the long-and-slender portion 
of the anterior canal $\sim 4 \mathrm{~mm}$ from the cupula. A static preload was set by sinusoidally driving the indenter at $\sim 20 \mu \mathrm{m}$ peak-to-peak displacement and slowly lowering it until the afferent response indicated that continuous contact was made (Dickman and Correia 1989a; Rabbitt et al. 1995). This ensured the functional integrity of the canal during placement of the indenter and served to linearize the results about the preload displacement of $\sim 10 \mu \mathrm{m}$. In experiments in which the afferents were silent or unresponsive to indentation, the contact and displacement of the canal limb by the indenter were determined by use of the microscope and manipulator's micrometer and checked for each recorded afferent. The correspondence between mechanical indentation and angular head acceleration has been determined previously in several species; $1 \mu \mathrm{m}$ of indentation commutes to $\sim 7^{\circ} / \mathrm{s}$ angular head velocity in pigeon (Dickman and Correia 1989a) and to $\sim 4^{\circ} \% \mathrm{~s}$ in toadfish (Rabbitt et al. 1995) for sinusoidal stimuli below $\sim 2 \mathrm{~Hz}$. Canal indentation remains effective in eliciting afferent responses at higher stimulus frequencies, but the correspondence to angular head velocity becomes more complex. In the present study sinusoidal indentation stimuli were delivered at amplitudes of $\pm 1-10 \mu \mathrm{m}$ at a frequency of $0.01-10 \mathrm{~Hz}$. While we have not performed the extensive series of experiments necessary to calibrate this stimulus in chicks, comparison with results in other species suggests that the magnitudes of the transfer between indentation and rotation should prevail. Thus, our results are not absolute sensitivities but serve as control values for the experimental results that follow.

A small opening was made in the bone immediately below the anterior ampulla to expose the nerve branch to the crista. Discharge activity was recorded from the preganglionic fibers using $2 \mathrm{~mm}$ diameter glass microelectrodes containing a solution of either (1) $2 \mathrm{M}$ $\mathrm{NaCl}, 5 \mathrm{mM} \mathrm{KCl}$, and $100 \mathrm{mM}$ Tris buffer, (2) $3 \mathrm{M}$ $\mathrm{KCl}$, or (3) 2\%-3\% biocytin (Molecular Probes, Eugene, OR) in the first salt solution or in $1 \mathrm{M}$ potassium methylsulfate; the electrode DC impedance was between 30 and $60 \mathrm{M} \Omega$. Care was taken to avoid recording from afferents injured by microelectrode penetrations. With this proviso, we found no difference in response dynamics between extra- and intracellular afferent recording methods. Action potentials were conventionally amplified, 8-pole linear phase bandpass filtered between 0.01 and $10 \mathrm{kHz}$, displayed, and idealized as TTL pulses using an amplitude window discriminator circuit (FHC). In 8 experiments selected afferents were intracellularly labeled with biocytin after first characterizing the response of a larger sample of canal afferents in the animal. Cells were labeled, provided that the membrane potential was stable and $<-40 \mathrm{mV}$, using positive current pulses of 5-15 nA (2/s, 80\% duty cycle) for 2-7 min. Because of the limited number of treated animals available for the present study, single afferent injections would have limited the data set and were beyond the scope of the present study; therefore injections were made in $2-5$ afferents per animal.

Digital data acquisition was used (CED 1401Plus, Spike2) to sample the externally discriminated spike and stimulus trigger times at a resolution of $0.08 \mathrm{~ms}$; the analog output of the LVDT was used to monitor the indenter position, filtered at $100 \mathrm{~Hz}$ and sampled at 250 points/s. The LVDT signal was externally amplified to span the 12-bit range over $\pm 20 \mu \mathrm{m}$ maximum displacement to provide a $0.005 \mu \mathrm{m}$ resolution.

\section{Data analysis}

The gain and phase of the first harmonic of afferent response with respect to stimulus were computed for $3-50$ consecutive cycles at a time by selecting portions of the record using an interactive graphical analysis procedure written as macros in Igor (WaveMetrics). The stimulus trigger was used as the reference time to generate 100-180 bin/cycle phase histograms of the stimulus and the afferent response. Figure 1 shows a control response to illustrate the method (31-dayold untreated chick). The afferent firing rate $[\mathrm{imp} / \mathrm{s}$ $=(\text { interspike interval })^{-1}$; upper trace] in response to $1 \mathrm{~Hz}$ indentation (lower trace) over 8 consecutive cycles is presented in panel $\mathrm{A}$, and the averaged response is given in panel $\mathrm{B}$ as a phase histogram. The amplitude and phase shown in $\mathrm{C}$ were determined by fitting the histogram with a sine wave of frequency equal to the primary stimulus frequency. Gain (imp/ $\mathrm{s} / \mu \mathrm{m})$ is defined as the magnitude of the afferent firing rate modulation $(\mathrm{imp} / \mathrm{s})$ divided by the magnitude of the indentation stimulus $(\mu \mathrm{m})$, and phase is defined as the angle $\left({ }^{\circ}\right.$, distance on the phase histogram) between the peak of modulation and the peak indentation displacement; in Figure 1B, the afferent gain was $11.3 \mathrm{imp} / \mathrm{s} / \mu \mathrm{m}$ and the peak modulation leads the peak stimulus by $29^{\circ}$. The afferent's gain and phase of response as a function of the frequency of indentation was determined by varying the frequency from typically $0.1-10 \mathrm{~Hz}$ at selected amplitudes (Fig. 1C). For particularly large amplitude or high frequency stimuli, the firing rate of some afferents was driven to zero (cutoff) over a portion of the stimulus cycle. In the least-squares fitting procedure, no numerical value was assigned to bins lacking firing rate data. This procedure results in sinusoidal curve fits that can take on negative values in cutoff regions of the afferent response cycle. In the example given in Figures 1A and $\mathrm{B}$, the afferent had a continuous modulation for $\pm 4.5 \mu \mathrm{m}$ stimuli but was silenced during a portion of the inhibitory phase of $\pm 10 \mu \mathrm{m}$ stimuli at $>1 \mathrm{~Hz}$. Since the cutoff is a highly nonlinear process, the 

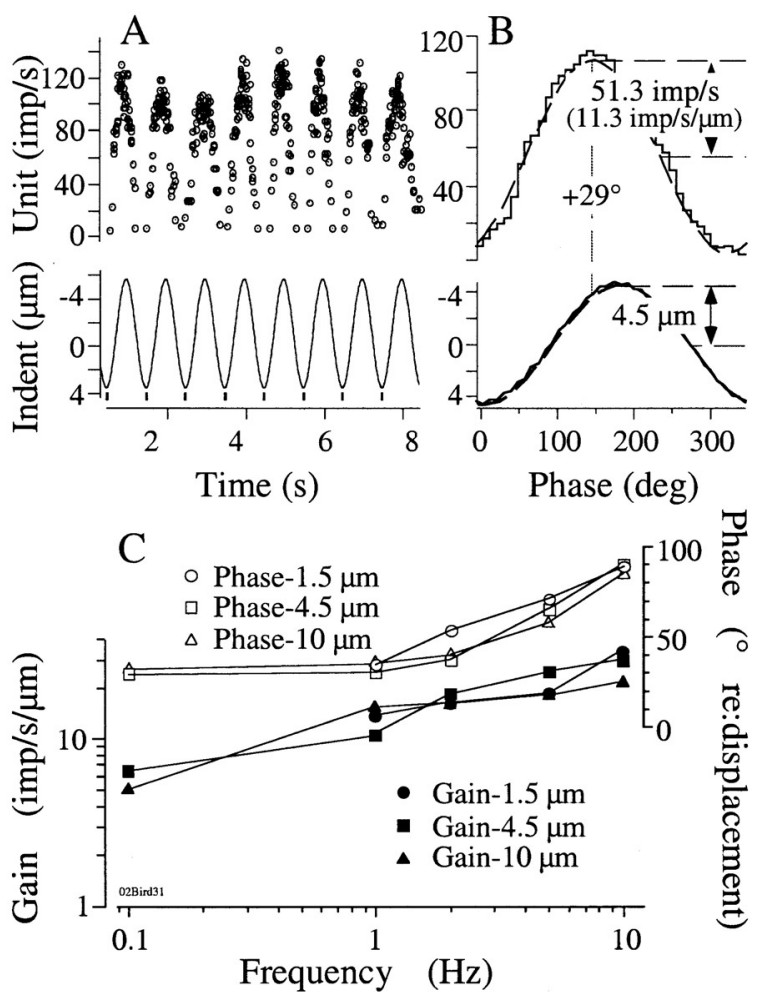

FIG. 1. Calculation of afferent responses to mechanical canal stimulation. Records were taken from an untreated chick. A Raw records showing the firing rate modulation (upper trace, in imp/s) to 8 consecutive cycles of sinusoidal indentation at $1 \mathrm{~Hz}, \pm 4.5 \mu \mathrm{m}$ (lower trace, in $\mu \mathrm{m})$; peak upward deflection of the indent stimulus $(-4.5 \mu \mathrm{m})$ is maximum upward displacement of the piezoelectric microactuator which mimics an ipsilaterally directed head movement. B Records of $\mathbf{A}$ were averaged and displayed in phase histograms. The response gain (afferent output/indent input) was calculated by dividing the firing rate modulation $(51.3 \mathrm{imp} / \mathrm{s}$ in this example) by the indent amplitude $(4.5 \mu \mathrm{m})$; the response phase is the angle between the output and input peaks. C Same afferent as in $\mathbf{A}$ and $\mathbf{B}$ was examined at multiple tests, from 0.01 to $10 \mathrm{~Hz}$ at three amplitudes as indicated, and the gain (filled symbols) and phase (open symbols) as function of stimulus frequency are plotted to illustrate the relative linearity of response at these parameters of stimulation.

curve-fitting procedure in these records results in estimates, and not absolute values, of the gain and phase. Both the DC component of the modulation, defined as the rate at half of peak-to-peak modulation, and the average rate, defined as the number of impulses divided by stimulus cycle time, were computed; the former measure assisted in detecting large cutoff responses and the latter was used as a measure of firing rate characteristics during stimulation. Gain measures were considered unreliable when the afferent fired less than one-half the stimulus cycle, and the test was repeated at a lower stimulus amplitude to induce a more full cycle modulation. Samples of firing rate $>30 \mathrm{~s}$ in length (from 120 to $>36,000$ interspike intervals) in the absence of canal indentation were taken in most instances to determine the afferent background discharge properties. The degree of discharge regularity was evaluated by determining the coefficient of variation (CV) of discharge, defined as the standard deviation of the interspike intervals divided by mean interval. While normalized CV provides a more absolute measure of regularity than CV (Goldberg et al. 1984), it was not calculated here because the necessary coefficients for canal afferents in this species are undetermined. Statistical comparisons between two different experimental groups or data within an individual experiment were performed using the nonparametric unpaired Mann-Whitney or paired Spearman rank correlation tests, and indicated levels of statistical probability are two-tailed values (Instat). Mean values are reported along with $\pm 1 \mathrm{SD}$ in the text and tables. "Silent" fibers were encountered in the "early" and "intermediate" periods following streptomycin treatment. These fibers had normal resting potentials $(\sim-65 \mathrm{mV})$ but lacked a background firing rate and could not be driven to discharge by mechanical labyrinth stimulation.

\section{Histology}

At the end of the experiment the animal was given an overdose of pentobarbital sodium and transcardially perfused with 100-500 cc heparinized saline followed by an equal volume of a fixation solution containing either (1) $2 \%$ paraformaldehyde, $2.5 \%$ glutaraldehyde, and $0.1 \mathrm{M}$ sucrose in $0.1 \mathrm{M}$ phosphate buffer (pH 7.4) for morphometric analysis or (2) $4 \%$ paraformaldehyde and $0.2 \%$ picric acid in $0.1 \mathrm{M}$ phosphate buffer ( $\mathrm{pH}$ 7.4) for biocytin immunohistochemistry. One to 2 cc of fixative was slowly injected in the oval and round windows to perfuse the labyrinth; in some cases the fixative was also injected directly toward the cupula through a cut made in the limb of the anterior or horizontal canal. In the biocytin experiments the entire labyrinth was exposed by dissection, removed, and placed in fixative for 1-2 days, then stored in phosphate-buffered saline (PBS) until prepared for biocytin immunohistochemistry.

Since the time course of hair cell regeneration has been documented in the chick's anterior semicircular canal (Weisleder and Rubel 1993), a morphometric analysis was performed on only a few selected chicks. Complete details of the preparation and analysis of the tissue for morphometry can be found in previous studies (Weisleder and Rubel 1993; Carey et al. 1996). Briefly, the animal was perfused as described above, and the labyrinth was extracted and post-fixed. Nucleus-bearing hair cells with a visible nucleolus were identified from $2 \mu \mathrm{m}$ transverse sections of the anterior crista under a light microscope at 400X magnification with Nomarski optics. Using the nomenclature of 
Wersäll (1956), hair cells were typed as I or II by the nature of the afferent ending contacting the cell: a type I hair cell was contacted by a complete calyx ending and a type II hair cell was contacted by an afferent ending that did not completely surround the cell. The number of calyx-bearing and noncalyx-bearing hair cells per $100 \mu \mathrm{m}$ length of basement membrane along the axial length of the crista was counted 6-8 times and averaged to provide a value of calyxbearing and noncalyx-bearing hair cell density, respectively.

To reveal the morphology of the afferents intracellularly stained with biocytin, the anterior crista and an adjoining portion of its nerve were freed from the surrounding structures, rinsed several times in PBS, and incubated for 3-4 hours in a solution of avidin biotin-horseradish peroxidase complex (ABC; 1:50 dilution; Vector Laboratories) and $0.25 \%$ Triton X-100 in PBS, followed by a 4-10 min soak in a solution of $0.05 \%$ diaminobenzidine (DAB) and $0.03 \% \mathrm{H}_{2} \mathrm{O}_{2}$ in PBS as described (Boyle et al. 1991). After rinsing in PBS, the labyrinth was imbedded in EPON and serially cut in $\sim 50 \mu \mathrm{m}$ sections, mounted, and coverslipped. Individual sections were examined at the light microscopic level using air, oil, or water-immersion objective lenses. Images were captured with a film back plane, on $35 \mathrm{~mm}$ film, or digitally, imported through a slide scanner or directly into Adobe Photoshop, contrast rendered, and printed on a dye-sublimation printer.

\section{RESULTS}

\section{Control responses in untreated chicks}

A total of 130 afferents were recorded in 7 untreated, control chicks ranging in age from 15 to 67 days (mean $=35 \pm 17$ days). These results are not meant to be an exhaustive survey of the anterior canal nerve response dynamics but only meant to serve as a benchmark to evaluate and compare the data obtained in the streptomycin-treated chicks.

Figure 2 provides the firing and response properties of 49 afferents recorded in a 29-day-old control. Sufficient records of background firing were obtained in 28 of the 49 afferents (panels A-C). Panel A gives the individual firing rate against its coefficient of variation (CV). Similar to afferents in other species, background firing rate $($ mean $=68 \mathrm{imp} / \mathrm{s} \pm 44$ indicated by dashed cross; $n=28$ ) showed a negative relationship to $\mathrm{CV}$ (mean $=0.38 \pm 0.34 ; n=28)$ : the higher the firing rate, the more regular was the spacing of the interspike intervals (lower CV value; $p<0.001$ ). No significant relationship was found between the afferent's regularity of background discharge and either its gain (panel $\mathrm{B}$; mean $=6.2 \pm 3.4 \mathrm{imp} / \mathrm{s} / \mu \mathrm{m} ; n=28$ ) or phase of response (panel $\mathrm{C}$; mean $=28^{\circ} \pm 16^{\circ} ; n=28$ ). In panels $\mathrm{D}$ and $\mathrm{E}$, the data from the 49 afferents (open circles) are shown and a comparison will be made between these afferents and those in a streptomycintreated chick of similar age. Response gain covaried with phase (panel $\mathrm{D} ; n=49$ ), with highly sensitive afferents having greater phase leads $(p<0.001)$; relatively low gain afferents (e.g., $\leq 2 \mathrm{imp} / \mathrm{s} / \mu \mathrm{m})$ showed the widest variation in phase from $-16^{\circ}$ lag to $55^{\circ}$ lead. Response gain and average rate (mean $=77 \pm 43$ $\mathrm{imp} / \mathrm{s} ; n=49$ ) were unrelated (panel E). Similar correlations in firing rate $(n=82)$ and response characteristics $(n=130)$ were found for the entire population of control responses in 7 untreated animals, and no apparent differences were observed in these animals as a function of age; therefore, the control responses were averaged and presented as one group in Figure 7 and Table 1.

The responses of 59 control afferents as a function of the frequency of indentation are presented in the plot of Figure 3. The responses of two afferents from the same animal are highlighted to illustrate the variation in dynamics observed. One afferent was tested from 0.01 to $10 \mathrm{~Hz}$ (dashed curves) and showed a pronounced gain increase beginning at $\sim 0.2 \mathrm{~Hz}$; the other afferent (solid curves) had a more consistent gain over the tested range of $0.1-10 \mathrm{~Hz}$. For the control population, gain increased by $\sim 2.5$-fold per decade of frequency and the phase was $\sim 30^{\circ}-40^{\circ}$ advanced to indent position over $\sim 2$ decades, from 0.05 to $5 \mathrm{~Hz}$ (also see Fig. 6).

\section{Responses in streptomycin-treated chicks}

Seventeen chicks provided morphological and/or afferent data to document the recovery of canal function following streptomycin-induced hair cell loss. Data are presented in 3 groups based on days after streptomycin treatment: early period from 14 to 18 days $(n=8)$, intermediate period from 28 to 34 days $(n=5)$, and late period from $>38$ days $(n=4)$.

Early period. Chicks in the early period of recovery were most markedly different from controls. Afferent recordings were attempted in 8 chicks ranging from 14 to 20 days poststreptomycin treatment. In 5 chicks no firing rate data could be obtained. In one chick (14 days poststreptomycin), anterior canal fibers on both sides could not be penetrated with the glass microelectrode. This is an apparent result of the streptomycin treatment, as such an impenetrable sheath was not seen in controls. In the other 4 chicks no background or indent-induced firing rates could be detected in $>30$ electrode penetrations of the nerve, and $\geq 5$ "silent" fibers having zero current membrane potentials $\leq-40 \mathrm{mV}$ were found in each.

Recordings were successful in 3 chicks at 14-18 days 

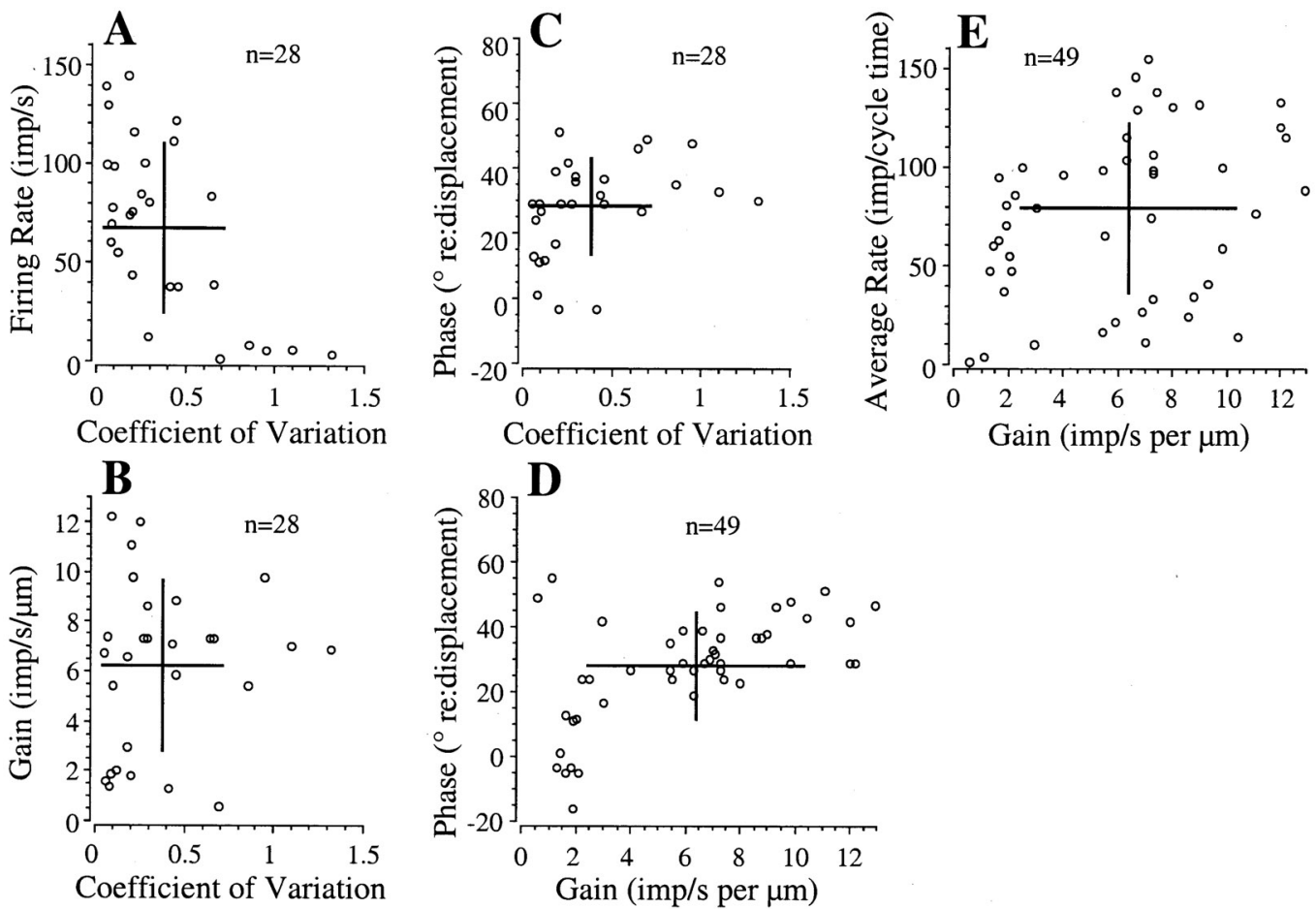

FIG. 2. Firing rate and response properties of canal afferents in control chick. The regularity of background discharge, measured by the coefficient of variation (CV), is plotted against the afferent firing rate (A), and the response gain (B) and phase (B) to a $1 \mathrm{~Hz}$ indent stimulus. The response gain is plotted against the response phase (D)

following streptomycin treatment. Data are presented in Figures 4, 5, 6, 7, 8, 10 and in Table 1 and Table 2. In each chick $\geq 10$ "silent" afferents were also intracellularly recorded and in some cases could be driven to discharge by passing current through the bridge circuit of the amplifier. These afferents exhibited deep resting potentials of $\leq-65 \mathrm{mV}$ and had no background or indent-induced discharge.

Figure 4 shows the firing behavior of 4 afferents, 2 each from a 14 day (Bird \#10, panels A and B) and an 18 day poststreptomycin chick (Bird \#3, panels $\mathrm{C}$ and $\mathrm{D})$. The afferent in panel $\mathrm{A}(\mathrm{CV}=0.26)$ and that in panel $\mathrm{C}(\mathrm{CV}=0.47)$ represent the largest magnitude modulations observed in the early period following streptomycin. In panel $\mathrm{C}$ both the gain and particularly the phase of response varied widely over 8 consecutive cycles: $0.54-1 \mathrm{imp} / \mathrm{s} / \mu \mathrm{m}$ and $10^{\circ}-75^{\circ}$ at $1 \mathrm{~Hz}$ and $0.15-1.34 \mathrm{imp} / \mathrm{s} / \mu \mathrm{m}$ and $11^{\circ}-75^{\circ}$ at 2 $\mathrm{Hz}$; this variability in modulation from cycle to cycle is not seen in control afferents (Fig. 1A). These best responses are roughly 25-fold below the average of the best responses recorded in each of the 7 controls (mean $23.8 \mathrm{imp} / \mathrm{s} / \mu \mathrm{m} \pm 15.0$; range-13.6-57.3). No modulation was detected in the low firing rate, irregularly discharging $(\mathrm{CV}=0.57)$ afferent in panel $\mathrm{B}$, or in the high firing rate, regularly discharging $(\mathrm{CV}=$ 0.06 ) afferent in panel D. In the 3 chicks, $50 \%$ (36/ and average rate (E, defined as the number of impulses in a cycle divided by cycle time). The dashed crosses in each plot are the mean $\pm \mathrm{SD}$. Note the wide range of gain values for afferents having the most regular spacing of interspike intervals $(\mathrm{CV}<0.1)$.

72 afferents) had a background firing rate but exhibited no response to the indent stimuli.

Figure 5 plots the relationship between the background firing and response characteristics to a $1 \mathrm{~Hz}$ $( \pm 5-10 \mu \mathrm{m})$ stimulus of afferents recorded in a 26day-old chick at 14 days poststreptomycin (filled circles; Bird \#10; same chick as in Figs. 4A and B); background data were available for 34 of the 47 afferents. Data presented in Figure 2 from a control chick of similar age (open circles) are plotted for comparison. Within the experimental chick, the background rate was negatively related $(p<0.01)$ to $\mathrm{CV}$, but no other significant correlation was found between the $\mathrm{CV}$, the response gain or phase, or the average rate. Compared with controls, the firing rate and gain were significantly attenuated $(p<0.001)$ and the firing rate was more irregular in pattern $(p<0.01)$ for the streptomycintreated chick.

The averaged responses of 16 afferents as a function of stimulus frequency taken from the same chick (Bird \#10) are shown in Figure 6 (filled circles). To be included in the plot, each afferent had to exhibit a reliable response for at least two or more frequencies, and a "no response" at a particular frequency was accepted. For example, 6 afferents responded to $0.5-2$ $\mathrm{Hz}$ stimuli but not to those at 5 or $10 \mathrm{~Hz}$; and 2 responded to a $5-10 \mathrm{~Hz}$ stimulus but not for stimuli 


\begin{tabular}{|c|c|c|c|c|c|c|c|c|}
\hline \multirow[b]{3}{*}{ Bird } & \multirow[b]{3}{*}{ Days post } & \multicolumn{7}{|c|}{ Afferent discharge properties of control and poststreptomycin chicks } \\
\hline & & \multicolumn{3}{|c|}{ Background discharge } & \multicolumn{4}{|c|}{ Response at $1 \mathrm{~Hz}$} \\
\hline & & $n$ & $\begin{array}{l}\text { Rate } \\
(\mathrm{imp} / \mathrm{s})\end{array}$ & $C V$ & $n$ & $\begin{array}{l}\text { Gain } \\
(\mathrm{imp} / \mathrm{s} / \mu \mathrm{m})\end{array}$ & $\begin{array}{c}\text { Phase } \\
(\rho)\end{array}$ & $\begin{array}{l}\text { Average rate } \\
\text { (imp/cycle time, }\end{array}$ \\
\hline 10 & 14 & 34 & $\begin{array}{l}22 \pm 23^{* *} \\
(1-109)\end{array}$ & $\begin{array}{l}0.67 \pm 0.43^{* *} \\
(0.07-1.9)\end{array}$ & 47 & $\begin{array}{l}0.19 \pm 0.21^{* *} \\
\quad(0-0.9)\end{array}$ & $\begin{array}{c}35 \pm 21 \\
(78 \text { to }-12)\end{array}$ & $\begin{array}{l}26 \pm 28^{* *} \\
(2-109)\end{array}$ \\
\hline 19 & 16 & 4 & $\begin{array}{c}32 \pm 25 \\
(9-65)\end{array}$ & $\begin{array}{c}0.76 \pm 0.41^{*} \\
(0.36-1.1)\end{array}$ & 14 & $\begin{array}{l}0.41 \pm 0.54^{* *} \\
\quad(0-1.6)\end{array}$ & $\begin{array}{c}-22 \pm 38 \\
(18 \text { to }-66)\end{array}$ & $\begin{array}{l}45 \pm 24^{*} \\
(10-80)\end{array}$ \\
\hline 3 & 18 & 12 & $\begin{array}{l}42 \pm 44^{*} \\
(13-155)\end{array}$ & $\begin{array}{c}0.56 \pm 0.40 \\
(0.06-1.33)\end{array}$ & 13 & $\begin{array}{l}0.16 \pm 0.3^{* *} \\
\quad(0-0.7)\end{array}$ & $\begin{array}{l}35 \pm 21 \\
(95-42)\end{array}$ & $\begin{array}{l}44 \pm 39 * \\
(13-154)\end{array}$ \\
\hline Early & & 50 & $27 \pm 30^{* *}$ & $0.64 \pm 0.43^{* *}$ & 74 & $0.22 \pm 0.32^{* *}$ & $27 \pm 33$ & $36 \pm 38^{* *}$ \\
\hline 13 & 28 & 20 & $\begin{array}{l}53 \pm 42 \\
(1-180)\end{array}$ & $\begin{array}{l}0.67 \pm 0.45^{* *} \\
(0.07-1.6)\end{array}$ & 26 & $\begin{array}{c}1.7 \pm 2^{* *} \\
(0-7.2)\end{array}$ & $\begin{array}{l}62 \pm 10 \\
(75-41)\end{array}$ & $\begin{array}{l}62 \pm 39 \\
(2-178)\end{array}$ \\
\hline 24 & 28 & 20 & $\begin{array}{l}40 \pm 22^{* *} \\
(1-102)\end{array}$ & $\begin{array}{l}0.44 \pm 0.26^{*} \\
(0.07-0.9)\end{array}$ & 40 & $\begin{array}{c}4.6 \pm 3.1^{*} \\
(0-10.3)\end{array}$ & $\begin{array}{c}29 \pm 14 \\
(56-2)\end{array}$ & $\begin{array}{l}46 \pm 28^{*} \\
(2-130)\end{array}$ \\
\hline 20 & 30 & 5 & $\begin{array}{l}64 \pm 31 \\
(31-113)\end{array}$ & $\begin{array}{r}0.37 \pm 0.3 \\
(0.13-0.9)\end{array}$ & 15 & $\begin{array}{l}4.6 \pm 5.1^{*} \\
(0-16.9)\end{array}$ & $\begin{array}{c}38 \pm 21 \\
(75 \text { to }-5)\end{array}$ & $\begin{array}{l}64 \pm 33 \\
(16-152)\end{array}$ \\
\hline 22 & 31 & 6 & $\begin{array}{l}42 \pm 35 \\
(16-110)\end{array}$ & $\begin{array}{l}0.81 \pm 0.34^{* *} \\
(0.27-1.1)\end{array}$ & 12 & $\begin{array}{l}7.6 \pm 5.5 \\
(0.8-17)\end{array}$ & $\begin{array}{c}21 \pm 13 \\
(73-21)\end{array}$ & $\begin{array}{l}58 \pm 30 \\
(20-128)\end{array}$ \\
\hline 7 & 34 & 23 & $\begin{array}{l}23 \pm 21^{* *} \\
(1-63)\end{array}$ & $\begin{array}{l}1 \pm 0.5^{* *} \\
(0.2-2)\end{array}$ & 28 & $\begin{array}{l}2.5 \pm 2.3^{* *} \\
(0-7.6)\end{array}$ & $\begin{array}{c}45 \pm 16 \\
(79-0)\end{array}$ & $\begin{array}{l}28 \pm 21^{* *} \\
(1-79)\end{array}$ \\
\hline Intermediate & & 74 & $40 \pm 32^{* *}$ & $0.69 \pm 0.47^{* *}$ & 121 & $3.7 \pm 3.7^{* *}$ & $42 \pm 19$ & $48 \pm 33^{* *}$ \\
\hline 16 & 38 & 7 & $\begin{array}{l}56 \pm 57 \\
(11-181)\end{array}$ & $\begin{array}{l}0.34 \pm 0.31 \\
\quad(0.12-1)\end{array}$ & 9 & $\begin{array}{l}1.2 \pm 1.1^{* *} \\
(0-3.9)\end{array}$ & $\begin{array}{c}20 \pm 19 \\
(41 \text { to }-26)\end{array}$ & $\begin{array}{l}55 \pm 32 \\
(16-129)\end{array}$ \\
\hline 18 & 39 & 9 & $\begin{array}{c}54 \pm 29 \\
(4-91)\end{array}$ & $\begin{array}{l}0.51 \pm 0.32^{*} \\
(0.13-1)\end{array}$ & 10 & $\begin{array}{c}3.8 \pm 4 \\
(0-12.2)\end{array}$ & $\begin{array}{c}38 \pm 57 \\
(114 \text { to }-29)\end{array}$ & $\begin{array}{l}77 \pm 41 \\
(16-143)\end{array}$ \\
\hline 23 & 40 & 9 & $\begin{array}{l}85 \pm 90 \\
(2-213)\end{array}$ & $\begin{array}{l}0.64 \pm 0.28^{* *} \\
(0.37-1.25)\end{array}$ & 18 & $\begin{array}{c}7.6 \pm 7.3 \\
(0.7-30)\end{array}$ & $\begin{array}{c}35 \pm 13 \\
(56-3)\end{array}$ & $\begin{array}{l}97 \pm 88 \\
(4-234)\end{array}$ \\
\hline 12 & 58 & 16 & $\begin{array}{l}50 \pm 55^{*} \\
(2-211)\end{array}$ & $\begin{array}{c}0.57 \pm 0.3^{*} \\
(0.07-1)\end{array}$ & 21 & $\begin{array}{c}6.3 \pm 5.6 \\
(0.6-17)\end{array}$ & $\begin{array}{l}43 \pm 17 \\
(67-10)\end{array}$ & $\begin{array}{l}60 \pm 52 * \\
(7-206)\end{array}$ \\
\hline Late & & 41 & $60 \pm 60^{*}$ & $0.54 \pm 0.31^{* *}$ & 58 & $5.5 \pm 5.9^{*}$ & $36 \pm 30$ & $73 \pm 62$ \\
\hline 7 Controls & & 82 & $\begin{array}{l}75 \pm 63 \\
(1-362)\end{array}$ & $\begin{array}{c}0.31 \pm 0.28 \\
(0.03-1.32)\end{array}$ & 130 & $\begin{array}{l}8.1 \pm 7.4 \\
(0.2-57.3)\end{array}$ & $\begin{array}{c}25 \pm 19 \\
(73 \text { to }-16)\end{array}$ & $\begin{array}{l}87 \pm 65 \\
(3-344)\end{array}$ \\
\hline
\end{tabular}

${ }^{*} p<0.05$
$* * p<0.01$

at $<2 \mathrm{~Hz}$. This behavior was not observed in controls. At all tested frequencies $(0.5-10 \mathrm{~Hz})$, the gain was significantly $(p<0.01)$ lower than control. A high frequency gain enhancement (lower plot, in imp/s/ $\mu \mathrm{m}$ ) was observed from $0.22 \pm 0.31$ at $0.5 \mathrm{~Hz}$ to $0.40 \pm$ 0.55 ( $\sim 1.8$-fold increase) at $10 \mathrm{~Hz}$ but was considerably less pronounced than that observed in controls over the same frequency range $(8.8 \pm 5-25.9 \pm 15.8$, or $\sim 3$-fold increase). Phase of response (upper plot in Fig. 6), with the exception of the few responses obtained at $10 \mathrm{~Hz}$, was within the range of control.

The data from the 3 chicks in the early period are shown in Figure 7 (filled circles), which plots the background (panels A and B) and $1 \mathrm{~Hz}$ response (panels $\mathrm{C}$ and D) characteristics as a function of days poststreptomycin. The individual and group averages are given in Table 1. With the sole exception of the background firing rate of the few afferents recorded in one chick (Bird \#19) at 16 days poststreptomycin, the data were significantly different from control responses $(p<$ 0.05 or better, Table 1). Eleven control afferents had response gains $<1.6$, the maximum response gain observed in the early period (Table 1 ). In comparison only to these 11 low gain control afferents, the afferents recorded in the early period remained highly significantly different (at $p<0.01$ or better) for all parameters tested.

In sum, no afferent background or stimulusinduced discharges were obtained in the majority of experiments in the early period of recovery. In experiments in which afferents were excitable, the rate was low and afferents had a significantly reduced gain and negligible high frequency response to mechanical vestibular stimulation.

Several chicks in this series also participated in the study of the horizontal VOR of Carey et al. (1996). The VOR responses of one chick (Bird \#10) were measured at 11 days poststreptomycin, and the data are 


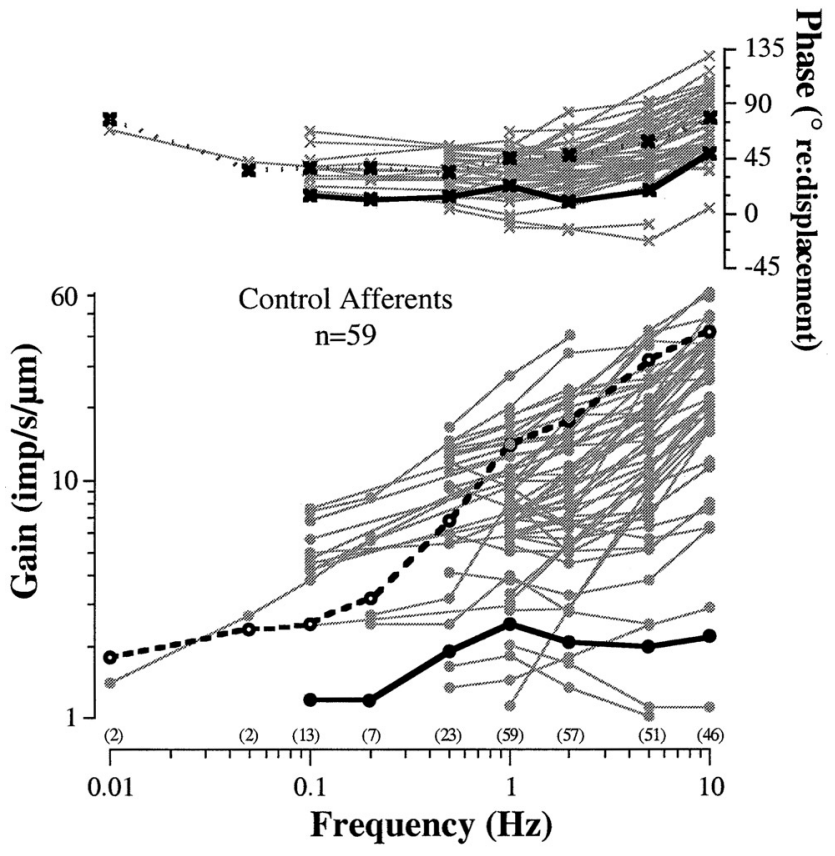

FIG. 3. Response characteristics as a function of stimulus frequency in 7 untreated chicks. A wide variation in response dynamics exists in the chick canal nerve, as illustrated by the gain (circles) and phase (x) responses of 59 individual afferents. Two individual afferents from the same chick are highlighted; one (filled circles and solid curves) had a consistent, low gain and relatively stable phase lead and the other (open circles and dashed curves) showed a pronounced frequency dependency in both gain and phase of response.

presented in Figure 8 (filled circles) along with the records taken from 4 age-matched control chicks $(X)$. The VOR gain of this chick is presented as filled triangles in the 2 weeks group of Figure 2 in Carey et al. (1996). Over the examined frequency range of $\sim 0.1-$ $1.4 \mathrm{~Hz}$, the gain of the VOR was reduced $(0.07-0.16)$ compared with controls $(0.19-0.46)$; at the lowest frequencies, 0.12 and $0.3 \mathrm{~Hz}$, the gains were $<0.1$ and basically indistinguishable from zero. The VOR phase, particularly at the more reliable measures taken at $\geq 0.5 \mathrm{~Hz}$, was similar to that of control responses. The poor performance of the VOR in the early period following streptomycin treatment qualitatively matches the severely reduced indent-induced response of the canal afferents recordings 3 days later (Figures 4, 5, 6, 7 and Table 1).

Table 2 gives the hair cell density, defined as number of cells $/ 100 \mu \mathrm{m}$, in the anterior canal crista of Bird \#10 (14 days poststreptomycin survival) and that of an aged-matched control. The anterior crista of this chick was nearly devoid of calyx-bearing hair cells (2\% of control, $p<0.01)$ and also showed a significant reduction $(70 \%$ of control) in total density of hair cells $(p$ $<0.05)$. The combined data from this chick indicate that the behavior of the horizontal VOR was severely impaired and the anterior canal afferents had a reduced background rate, a dramatic gain reduction (3\% of control) to mechanical vestibular stimulation, and a neuroepithelium in the early stages of hair cell regeneration after streptomycin toxicity.

Intermediate period. Five chicks ranging from 28 to 34 days posttreatment were studied. Panel A in Figure 9 shows an afferent response in a chick at 34 days posttreatment (Bird \#7) to a $1 \mathrm{~Hz}( \pm 11.5 \mu \mathrm{m})$ indent stimulus. The response appears to be within normal limits but was strikingly different from the absent or poor responses recorded during the early period following streptomycin. "Silent" fibers and unresponsive afferents were predominant features in the early period. In the intermediate period, "silent" fibers were infrequently encountered $(\sim 3 /$ chick $)$, and fewer recorded afferents $(16 / 121$ or $13 \%)$ having a background firing rate were unresponsive to mechanical stimulation (the $\mathrm{CV}$ and background rate of these 16 afferents was in the range of $0.07-1.0$ and $0.4-180$ $\mathrm{imp} / \mathrm{s}$, respectively). The averaged $( \pm \mathrm{SD})$ characteristics of the firing rate (panel $\mathrm{A}$ and $\mathrm{B}$, open circles) and response to a $1 \mathrm{~Hz}$ indent stimulus (panels $\mathrm{C}$ and D) are shown in Figure 7 as a function of days following treatment. The data of Bird \#7 stand out from those of the other chicks in this group. As seen in Figure 7 and in the measures given in Table 1, the firing properties of afferents in this chick more closely resemble those recorded during the early period poststreptomycin. The background rates were low, and noticeably absent were high rate $(>100 \mathrm{imp} / \mathrm{s})$ afferents. The discharge regularity was consistently irregular in its pattern. However, the response gain, still significantly lower than the gain of control responses $(p<0.001)$, was elevated tenfold $(p<0.001)$ over that of afferents in the early period. The background rate and response gain of afferents in the intermediate stages of regeneration moved closer to, but remained significantly different from, those measured in controls (Table 1). This finding can also be seen in the averaged responses of 63 afferents presented in the plots of Figure 6. The 63 afferents had on average a lower gain than control afferents at each tested frequency, but the gain enhancement over higher frequencies was comparable to that in control afferents.

Late period. Four chicks that ranged from 38 to 58 days poststreptomycin were studied. No "silent" or unresponsive afferents were encountered in these chicks. Figure 9B shows the response to a $1 \mathrm{~Hz}$ indent stimulus (first portion of record) and firing rate (later portion of record) of one afferent at 58 days (Bird \#12). The group averages given in Table 1 indicate that the afferents recorded were less significantly different from controls compared with their counterparts in the early and intermediate periods. However, as shown in Figure 7 (diamonds) considerable variability in firing 

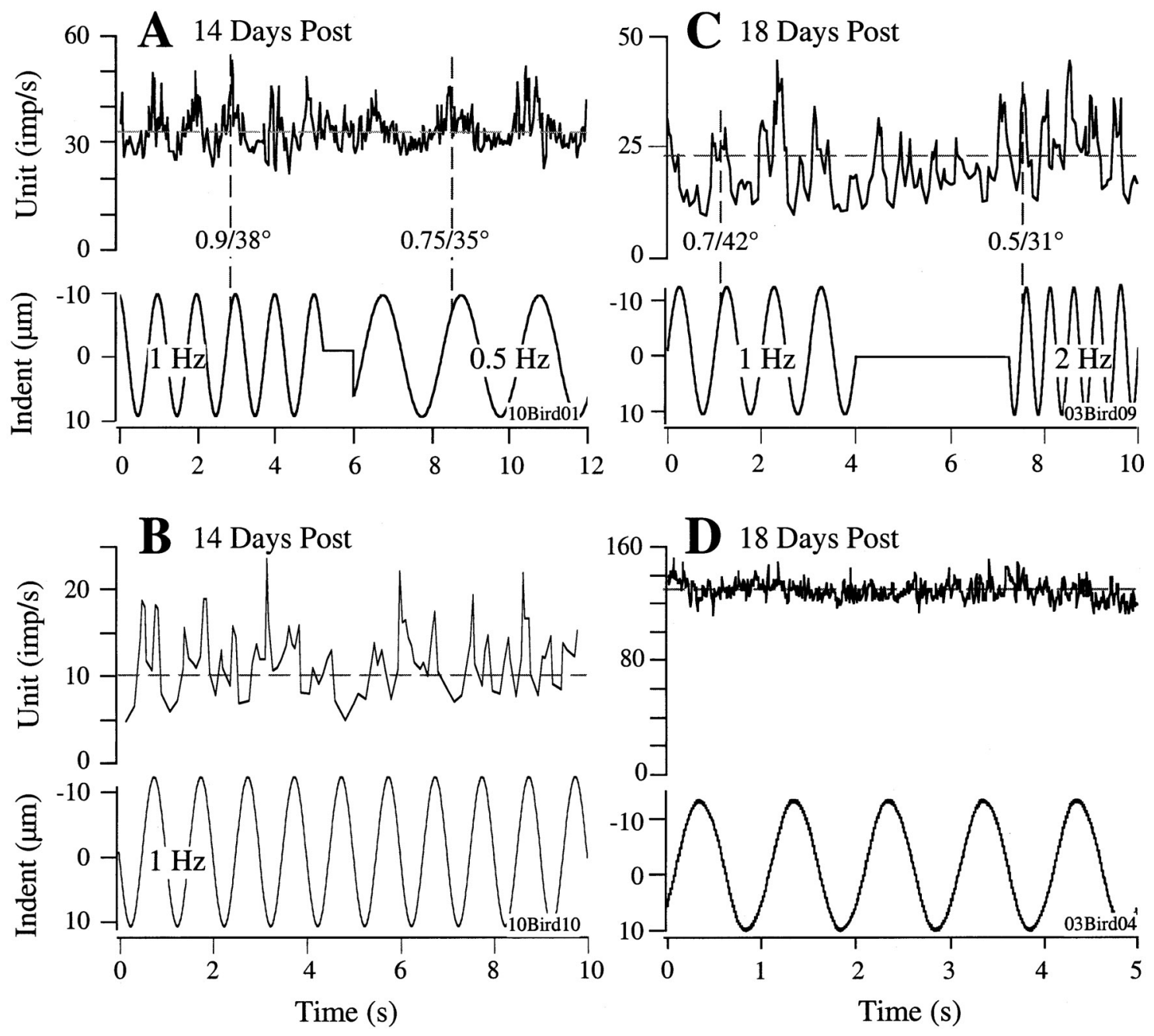

FIG. 4. Individual responses in chicks during the early period following streptomycin toxicity. Same format as Fig. $1 \mathrm{~A}$. A Best response recorded in a 14 days poststreptomycin chick; 20/47 (43\%) afferents were unresponsive to canal stimulation (an example is shown in $\mathbf{B}$ ).

C Best response recorded in an 18 days poststreptomycin chick; $7 / 13(54 \%)$ were unresponsive to canal stimulation (an example is given in $\mathbf{D})$.

TABLE 2

Hair cell density of control versus 14 day poststreptomycin chick $^{a}$

\begin{tabular}{llll}
\hline & \multicolumn{1}{c}{ Total } & Calyx-bearing & $\begin{array}{c}\text { Noncalyx- } \\
\text { bearing }\end{array}$ \\
\hline Control & $9.51 \pm 1.60$ & $2.45 \pm 2.22$ & $7.06 \pm 1.67$ \\
Bird \#10 & $6.78 \pm 0.93^{*}$ & $0.05 \pm 0.16^{* *}$ & $6.73 \pm 0.96$ \\
\hline
\end{tabular}

${ }^{a}$ Mean hair cell density (cells/100 $\mu \mathrm{m}$ sensory epithelium) in the anterio canal crista. Values are averages of 8 counts along the axial length of crista $( \pm S D)$. Separate counts of calyx-bearing and noncalyx-bearing hair cells were made. The major differences between the experimental chick and the agematched control chick are the reduced number of total hair cells $\left({ }^{*} p<0.05\right)$ and nearly complete absence of calyx-bearing hair cells at this stage in the regenerating crista $\left({ }^{* *} p<0.01\right)$. VOR was tested at 11 -day survival (see Fig. 8).

rate, discharge regularity, and the phase and gain of response to canal stimulation were found in these chicks, particularly those at 38-40 days poststrepto- mycin. These chicks also showed the widest variability in their responses as a function of stimulus frequency (Fig. 6).

The horizontal VOR of one chick (Bird \#12) was studied 3 days prior to the afferent recordings. The gain and phase of the VOR at the tested frequencies of $0.1-1.4 \mathrm{~Hz}$ were comparable to those of two agematched controls, and the hair cell density in the anterior canal of this chick did not statistically differ from an aged-matched control (Table 3). The gain and phase of response to anterior canal indentation of the 21 afferents recorded in this chick were not significantly different from control (Table 1 ). Thus, after $\sim 8$ weeks poststreptomycin, the sensory epithelium has regenerated, the behavior of the horizontal VOR is normal, and the anterior canal afferent firing and response characteristics reflect less differences from control afferents. 

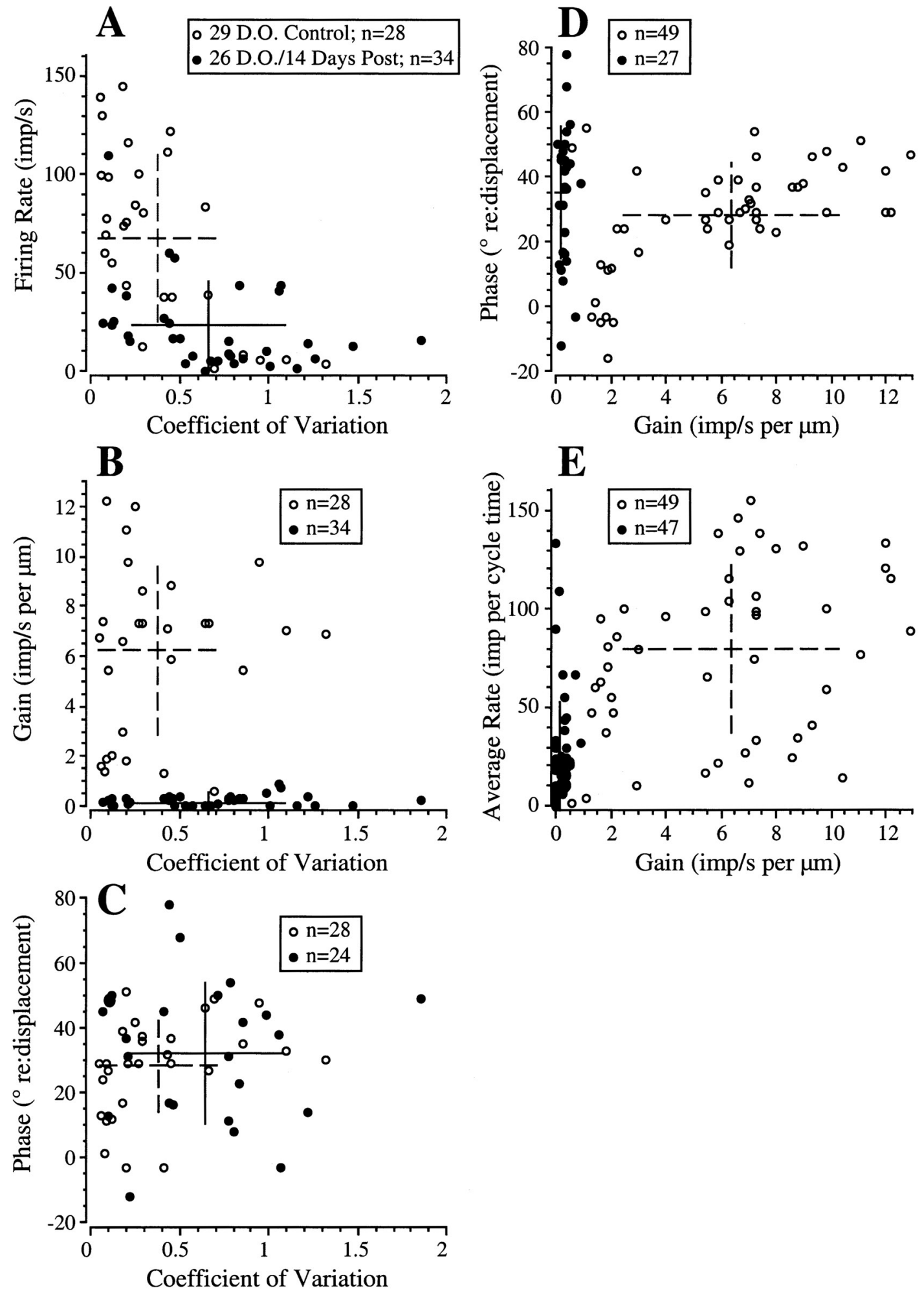

FIG. 5. Firing rate and response properties of canal afferents in 2 chicks of comparable age: treated vs. control. Same format as Figure 2. Open circles represent the afferent data from the 29-day-old control chick (360 g body weight) shown in Figure 2, and the filled circles are the data from a chick of similar age (26 days old, $200 \mathrm{~g}$ ) but examined 14 days poststreptomycin toxicity. The dashed and solid crosses in each plot are the mean $\pm \mathrm{SD}$ in control and streptomycintreated chicks, respectively. No phase value is given in $\mathbf{C}$ and $\mathbf{D}$ for

afferents of the treated chick having a background firing rate but unresponsive to the indent stimulus. Except for the phase of response, the two populations are strikingly different, particularly in respect to background firing rate and response gain. Number of afferents tested is indicated; differences in number exist in $\mathbf{A}-\mathbf{E}$ because the coefficient of variation was not tested in every afferent and no phase is calculated for unresponsive (0 gain) afferents. 

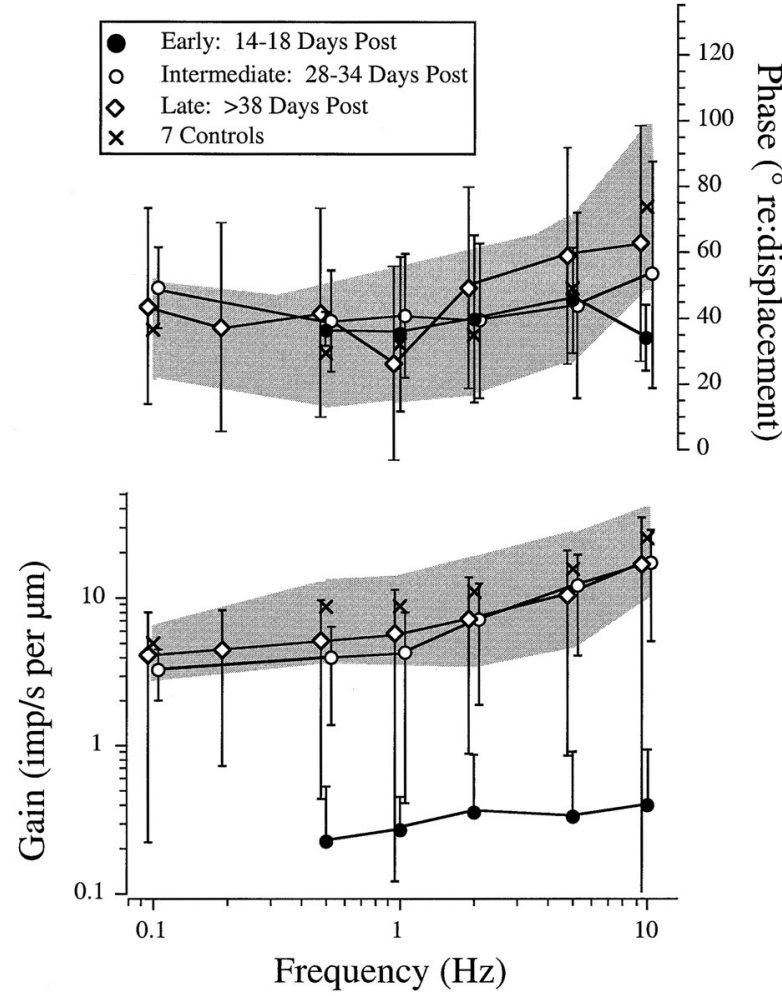

FIG. 6. Averaged gain and phase of response as a function of stimulus frequency (Bode plot) of afferents from early (filled circles), intermediate (open circles), and late (diamonds) periods following streptomycin treatment are compared with control responses in 7 untreated chicks $(\mathbf{X})$. Control responses are taken from the data presented in Figure 3; shaded region represents 1 SD. Note the dramatic gain reduction in afferents of early period chicks.
Morphology of labeled afferents.

The anterior canal crista and three intracellularly labeled afferents supplying the hair cell epithelium in two control chicks are shown in Figures 10(A-D). Panel A is a cross-sectional view of the crista made from a montage of 6 separate frames taken at a low power magnification (10X) near the midpoint of the long axis of the sensory hair cell epithelium. The chick's vertical canal is similar to other birds in that it possesses an anatomical peculiarity, the eminentia cruciatum (labeled crus in A), that separates the epithelium into two parts, each with their own nerve supply (Igarashi and Yoshinobu 1966). Vestibular nerve afferents contact the hair cells in chick by three different modes (see Lysakowski and Goldberg 1997 for a full description in mammal): calyx-only afferents surrounding one or more type I hair cells (example in B), bouton-only afferents supplying numerous type II hair cells (example in $\mathrm{C}$ ), and dimorphic afferents supplying one or more type I hair cells with a calyx and type II hair cells with boutons (example in D). The box in A encloses a labeled afferent that is enlarged in panel B. The afferent ended as calyx-only, surrounding 4 type I hair cells. Panel $\mathrm{C}$ shows an afferent ending as bouton-only at about midway along the long axis between the center and the planum; $>30$ bouton-type endings were detected issuing from dendritic processes covering a lengthwise span of $\sim 150 \mu \mathrm{m}$ of epithelium.

Individual or nonspecific labeling with biocytin was done in chicks at different days after streptomycin
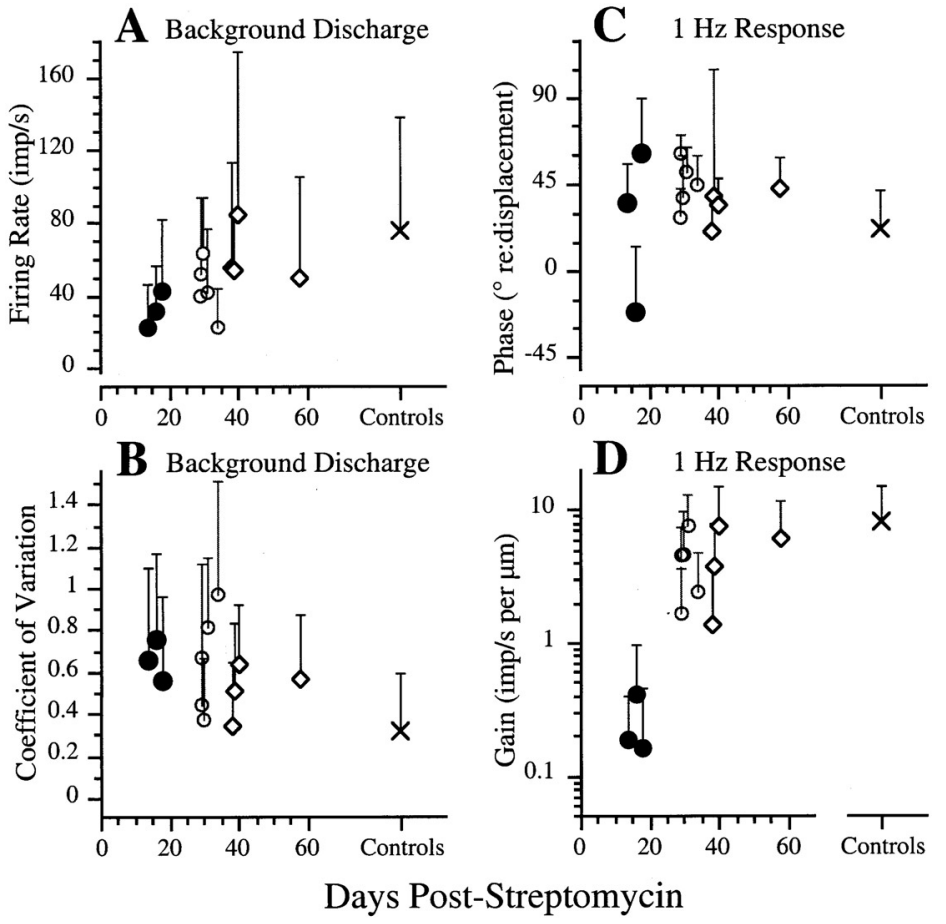

FIG. 7. Recovery of firing rate and response properties with time following streptomycin toxicity. The results (mean \pm SD) obtained from the individual chicks are plotted as a function of days poststreptomycin (abscissa). Control responses $(\mathbf{X})$ are given on the right side in each panel. Data from individual chicks within each group are shown with the same symbol: early (filled circles), intermediate (open circles), and late (diamonds) periods. Note the progressive recovery toward control values, usually accompanied by an increase in response variability, from the early to the late period during hair cell regeneration, particularly evident in background firing rate $(\mathbf{A})$, the regularity of discharge (B), and gain of response (D); phase of response can be measured only in responsive cells and was a poor indicator of the period of epithelial regeneration. 


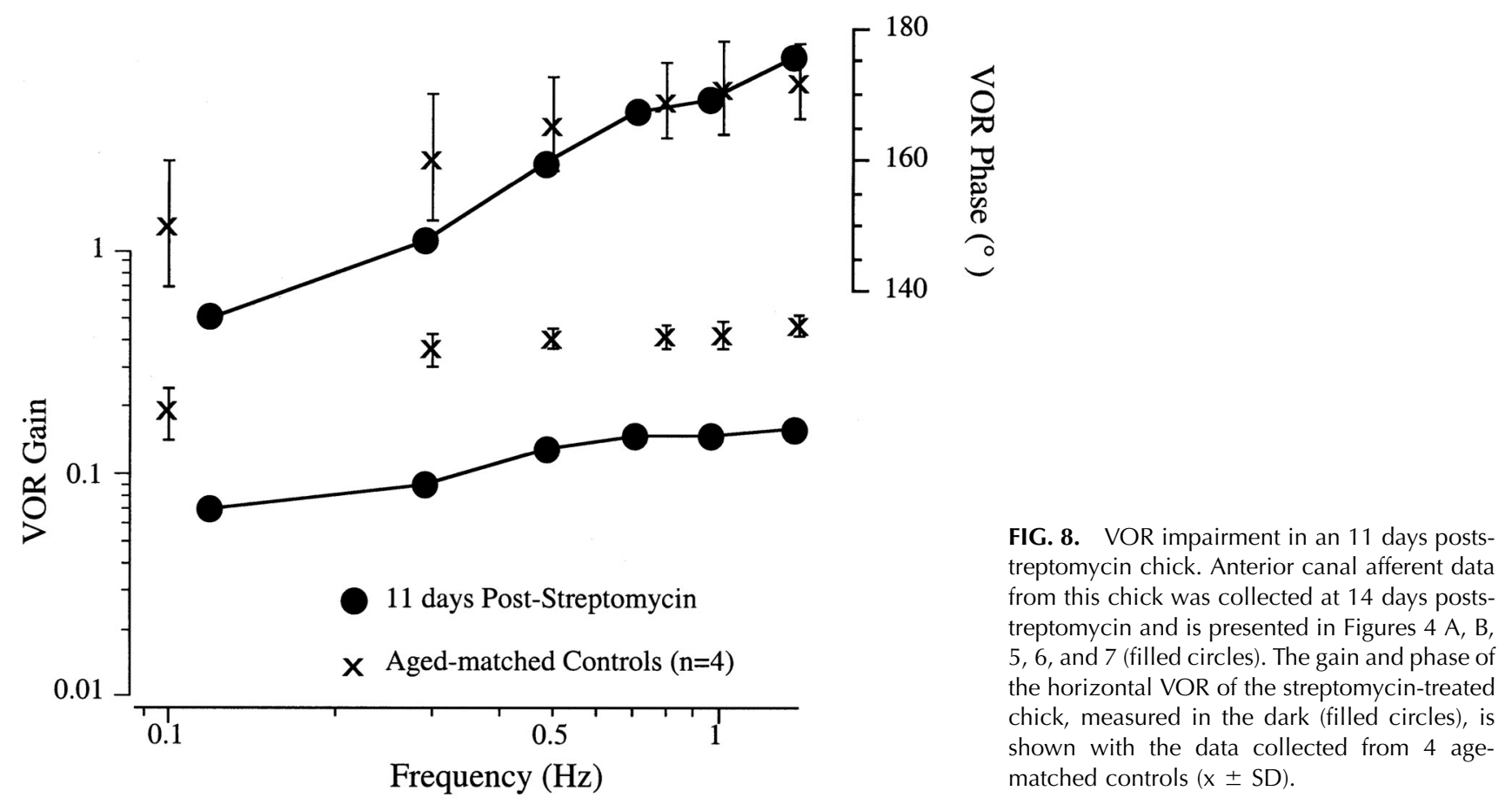

treatment. Panel D presents an intracellularly labeled dimorphic afferent midway between the crus and the planum in a control chick and is shown along side panel $\mathrm{E}$ for a comparison to the crista of a chick 15 days poststreptomycin. No hair cells or hair bundles were discernible in sections through the crista in this chick (early period), but afferent fiber fascicles were prominent up to the basement membrane. Ten "silent" afferents were intracellularly recorded in this animal, and none were found to have either a background firing rate or an induced discharge by mechanical canal stimulation; unsuccessful attempts were made to individually label several afferents. Biocytin crystals were also placed onto the exposed canal nerve, but labeled afferent processes failed to be recovered. Panel F shows a photomicrograph of one intracellularly labeled "silent" afferent (arrow) in a 17 days poststreptomycin chick (Bird \#21) that penetrated the basement membrane (red arrowhead) and extended into the supporting cell layer of the crista (black arrowhead). Although individual terminal specializations were undetected, it remains uncertain whether they were absent or not visible in the tissue. No firing rate activity was detected in this chick and $>7$ "silent" fibers were encountered. Unsuccessful attempts were made to recover seemingly well-labeled individual afferents in another chick at 16 days poststreptomycin (Bird \#19) for which firing rate data were obtained (included in Fig. 7 and Table 1); in this chick hair cells and hair bundles and afferent fascicles were clearly present in the anterior crista.

The dendritic structure and termination patterns of two afferents in two chicks in the intermediate period are shown in Figures $10 \mathrm{G}$ and $\mathrm{H}$; panel $\mathrm{G}$ is taken from a 28 days poststreptomycin chick (Bird \#24) and panel $\mathrm{H}$ is from a 31 days poststreptomycin chick (Bird \#22). A dimorphic afferent is shown in the two sections of panel G. The axon entered the epithelium (arrow), reversed its course, terminated with two calyx endings (upper section of panel), and extended $\sim 50 \mu \mathrm{m}$ to terminate with at least two calyx endings and $>5$ bouton-like endings (lower section of panel). Two afferents were injected in Bird \#22 (one recovered, panel $\mathrm{H}$ ), and both had relatively similar response properties: moderate to high gain (4.8 and $13 \mathrm{imp} / \mathrm{s} / \mu \mathrm{m})$, large phase leads $\left(71^{\circ}\right.$ and $\left.67^{\circ}\right)$, and moderate rates $(62$ and $29 \mathrm{imp} / \mathrm{s}$, respectively). The afferent shown in panel $\mathrm{H}$ ended with three calyxes on one side of the crista near its central region.

An afferent ending as a dimorph and labeled in a 40 days poststreptomycin chick (Bird \#23) is shown in Figure 10I; two other afferents were injected in this chick but were not recovered. However, the firing behavior of the three injected afferents was similar: moderate gains $(5.9 \pm 2 \mathrm{imp} / \mathrm{s} / \mu \mathrm{m})$, moderate phase leads $\left(37^{\circ} \pm 7^{\circ}\right)$, and moderate to high firing rates (86-220 imp/s).

\section{DISCUSSION}

The present study demonstrates that the background and mechanically induced discharges of anterior semicircular canal afferents in chick progressively recover 

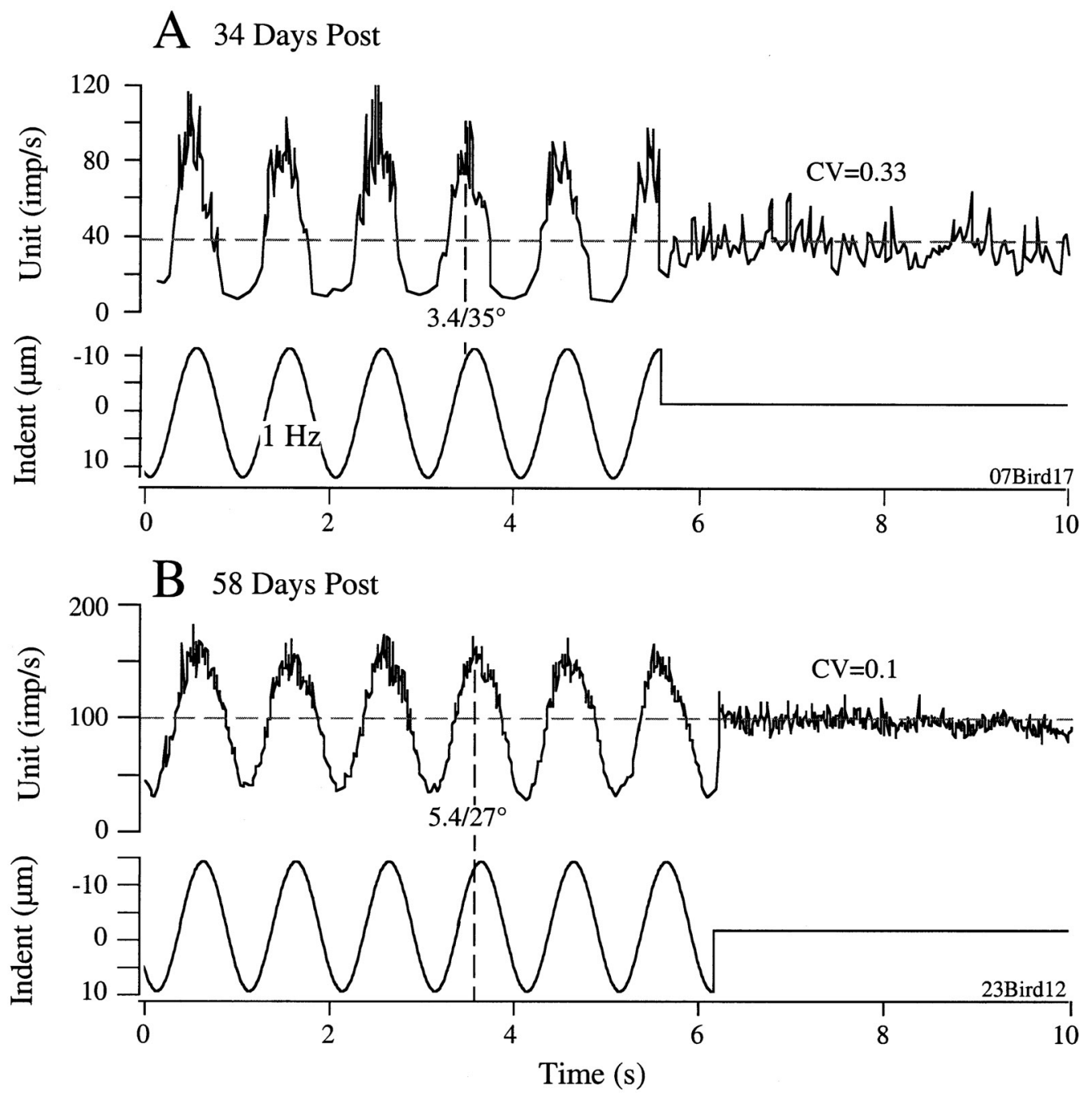

FIG. 9. Individual responses in chicks during the intermediate (A) and late (B) periods following streptomycin toxicity. Same format as Figure $1 \mathrm{~A}$.

\begin{tabular}{|c|c|c|c|}
\hline \multicolumn{4}{|c|}{$\begin{array}{c}\text { Hair cell density of control versus } 58 \text { day } \\
\text { poststreptomycin chick }{ }^{a}\end{array}$} \\
\hline & Total & Calyx-bearing & Noncalyx-bearing \\
\hline Control & $8.20 \pm 1.78$ & $3.08 \pm 3.04$ & $5.12 \pm 1.64$ \\
\hline Bird \#12 & $8.07 \pm 4.74$ & $1.38 \pm 1.30$ & $6.69 \pm 3.65$ \\
\hline
\end{tabular}

to an apparent normal function following the hair cell lost in the cristae by streptomycin treatment. The horizontal VOR and anterior crista hair cell density were also measured in one chick from the early period and one from the late period following streptomycin treatment. Although the rate of recovery of both the horizontal and vertical VOR following streptomycin is not yet known, we found significantly reduced anterior canal afferent responses, horizontal VOR, and anterior crista hair cell density in the early period chick and normal physiological, behavioral, and morphological measures in the late period chick. These results provide a neuronal basis for the functional recovery of the behavioral vestibulo-ocular (Carey et al. 1996) and vestibulocollic (Goode et al. 1999) reflexes observed in similarly treated chicks.

Fish and amphibians possess only type II hair cells, whereas mammals, birds, and lizards have both type I and type II hair cells. A simpler view is that higher vertebrates contain the afferent nerve calyx, lower vertebrates do not. The functional significance of the cell types and afferent innervation pattern still evades explanation. Favre and Sans (1979a,b) reported that postnatal development in mice originates with type II cells, the phylogenetically older cell type (Wersáll and Bagger-Sjöbäck 1974), followed by the appearance of type I cells and the nerve calyx. The present study was 

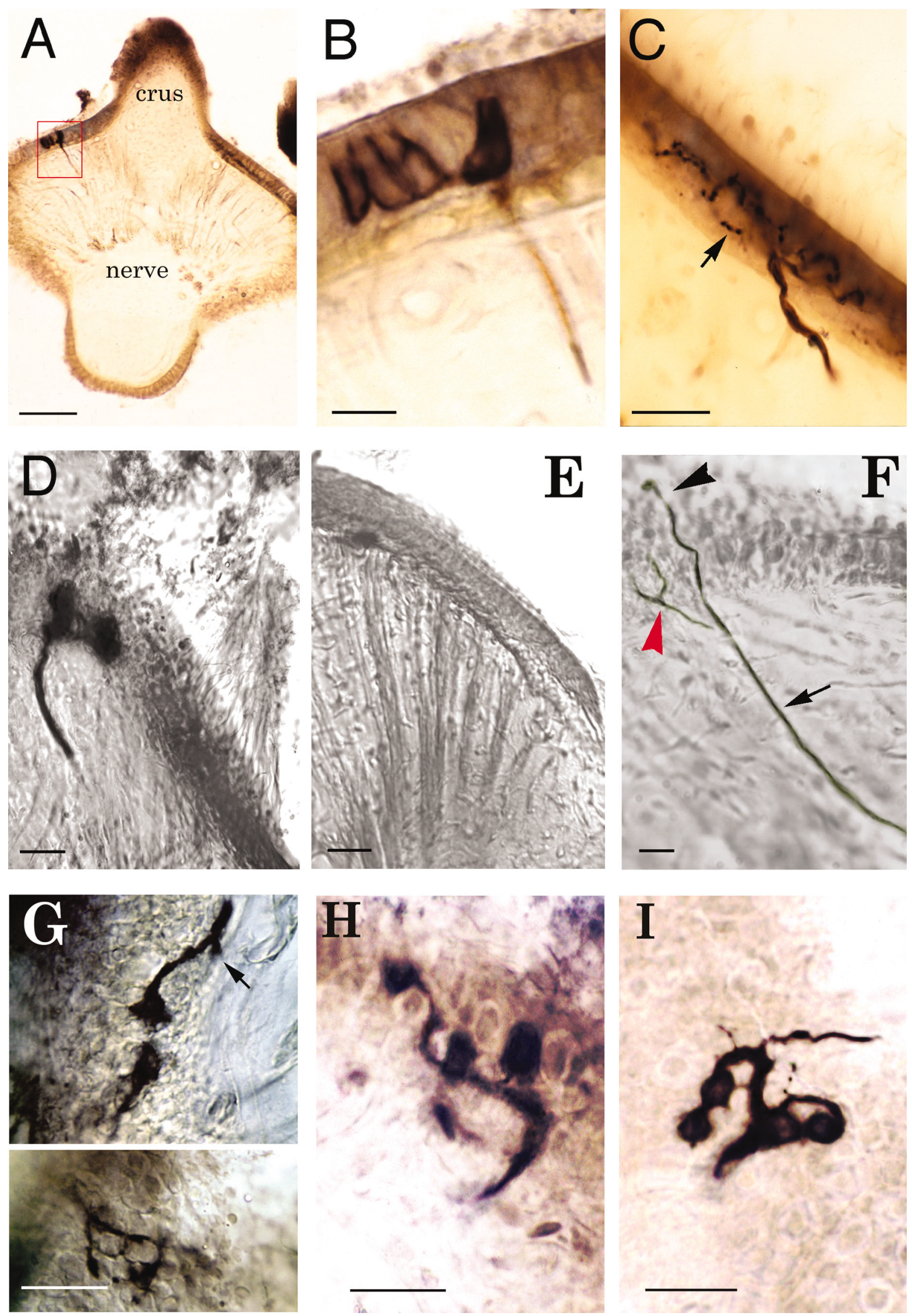

FIG. 10. Photomicrographs of the anterior canal crista and individual afferents in untreated $(\mathbf{A}-\mathbf{D})$ and in treated chicks during the early $(\mathbf{E}, \mathbf{F})$, intermediate $(\mathbf{G}, \mathbf{H})$ and late (I) periods following hair cell loss caused by streptomycin toxicity. Afferents were intracellularly labeled using biocytin. Calibration bars are $100 \mu \mathrm{m}(\mathbf{A})$ and $30 \mu \mathrm{m}(\mathbf{B}-\mathbf{I})$. See text for details. 
motivated by the results of Weisleder et al. (1995): 20 days after streptomycin, hair cells reoccupy the crista but the nerve calyx conspicuously is absent; the nerve calyx progressively returns and by 60 days the epithelium appears normal.

\section{Assignment of chicks to groups}

Chicks were assigned to three groups-early, intermediate, and late-based on days after streptomycin treatment. The criteria used for this scheme were mostly arbitrary, and the groups were compiled for descriptive purposes. Chicks in the early period represented a distinctive population, and those in the intermediate and late groups showed wide variations in firing behavior. For example, Bird \#7 (see Table 1) was studied 34 days posttreatment and had background discharge characteristics like those of chicks in the early period, and Bird \#16 at 38 days had afferents with relatively low response gains to stimulation but higher firing rates. The variability in these results is most likely due to extent of hair cell loss following systemic streptomycin administration and subsequent regeneration at the time of recording in each experiment as shown by Weisleder and Rubel (1993) and Carey et al. (1996). Hair cell counts were obtained in some cases, but not all, because of our efforts to obtain the morphology of individually labeled afferents. Studies done by others were designed to provide these measures (Weisleder et al. 1995), and we rely upon their data. The present results nevertheless indicate the relative time course of functional recovery of afferent background discharge and response to adequate vestibular stimulation.

Chick afferents were not subdivided in the early, intermediate, and late periods based on their regularity of discharge because no consistent relationship was found between the control afferents' background discharge properties and any measured parameter of their response to indentation (see Fig. 2). In untreated pigeons correlates were found between dynamic response properties to mechanical indentation and the CV and mean firing rate of horizontal canal afferents (Dickman and Correia 1989b). Factors for this discrepancy between canal afferents in the two bird species are unclear. They might include the anesthetic agents used, sample biases against smaller diameter fibers, or actual differences between the species. At present we have no empirical evidence to separate the recorded afferents into morphological subgroups based on synaptic specializations. Additional studies using extensive labeling of individual afferents are needed to establish the relationship between background and induced discharges and dendritic morphology.

\section{Restoration of vestibular function}

The appearance of background discharge in afferents still unresponsive to mechanical canal stimulation suggests that the afferents might re-establish synaptic contact with the newly regenerated hair cells before transduction is functionally restored. In the chinchilla crista, afferent fibers retract and almost completely disappear from sensory epithelium within one week following lesion (Lopez et al. 1997). In the chick the retraction of afferents appears to occur only if ototoxic drug damage is severe (Henning and Cotanche 1998). Whether or not (e.g., Fig. 10F) afferent fibers retracted in our chicks, recording background or induced discharges within the first 3 weeks following ototoxic treatment was quite unsuccessful. In 5 experiments done in chicks 14-20 days posttreatment, no quantitative afferent data were obtained. Afferent fibers could be penetrated intra-axonally in 4 of these chicks, but only a small percentage of fibers could be driven to discharge by passing depolarizing current, implying an abnormal or absent spike initiation in these fibers; in most cases only a deep resting membrane potential could be measured. No background or induced discharges were observed. The absence of normal impulse initiation suggests that the spike initiation area near the hair cell may be nonfunctional. Apparently the nodes of Ranvier also cannot support action potential initiation in these early, regenerating fibers. In two cases, biocytin was applied either nonspecifically to damaged fibers in the canal nerve or directly injected into individual fibers, but afferent processes failed to be observed in the crista. This finding suggests, but does not confirm, that afferent-to-hair cell synapses require between 2 and 3 weeks to re-establish. Although our data are suggestive of the above-mentioned mechanism, it must be emphasized that the occurrence of pathological impulse initiation in these afferents has not been ruled out. Ototoxic drugs can damage the synaptic structure of surviving hair cells and afferent terminals (Hackney et al. 1990). This might also account for the return of low level, irregular spontaneous activity in the absence of transduction. The wide variability of firing behavior of afferents posttreatment, particularly $>3$ weeks, observed in our study might reflect the variable time course of synapse formation and repair.

The hair cell's basolateral channels, which are responsible for resonant frequency tuning, if any, and are likely involved in the release of synaptic transmitter, might be absent or poorly developed in the early stages of regeneration. Evidence that lends some support to this idea comes from the study of Masetto and Correia (1997b) who measured the ionic currents of type II hair cells in the pigeon slice preparation following 
streptomycin treatment. They showed that the expression of the different ion channels takes weeks to reorganize in regenerating hair cells; most notable at this stage is the lower cell membrane capacitance (indicative of cell size) and lower total outward current peak slope conductance. By 9-10 weeks poststreptomycin, type II hair cells express all the passive and active properties of normal cells. As discussed by these authors, emergence of different ion channels follows an order similar to that found in developing cells of the chick otocyst (Sokolowski et al. 1993). Masetto and Correia's observations in the pigeon started at 3 weeks posttreatment, about a week after the time we were able to record afferent discharges in the chick and at which an occasional weak response could be induced. In a related report, Masetto and Correia (1997a) found that repopulation of the neuroepithelium with type II hair cells started at 22 days poststreptomycin treatment, providing a rationale for delaying their electrophysiological observations. It appears that the time course of morphological maturation and regeneration of the crista ampullaris posthatching is slower in the pigeon than in the chick, in line with the pigeon's slower development of its appearance and ability to fly (Lahaye and Cordiez 1965). Thus, we might expect the 3-week-old pigeon slices studied by Masetto and Correia (1997b) to be more representative of our data in the early period.

In a subsequent and related study to ours from Correia's lab ( $\mathrm{Li}$ and Correia 1998), the functional recovery of canal afferents in pigeons was surveyed poststreptomycin treatment. At 20 and 25 days posttreatment cells were found that had spontaneous discharges but could not be driven using rotational stimuli. Beginning 30 days poststreptomycin responses were observed that resembled control responses, although at about half their gain. Sampling at 10-day intervals return to normal followed an approximately systematic course in their studied parameters, including a derived adaptation time constant. Using a sumof-sines test to probe the cupula time constant, they also found that at their 30-day starting date the responses were normal, suggesting a normal stereocilia-cupula interface. In the chick background discharge appears first, even at twice the average of control afferents (Fig. 4D), but the initial responses are ragged (compare Figs. $4 \mathrm{~A}$ and $\mathrm{C}$, the best responses observed in these chicks, with Fig. 1A or 7B) and the gain of response is more than an order of magnitude less than control gain.

In conclusion, semicircular afferent structure and function returns to near normal values after $6-8$ weeks following ototoxic trauma. This recovery pattern fits well with the recovery of afferent dendritic morphology (present results), anterior canal hair cell density
(Weisleder and Rubel 1993; present results), horizontal canal hair cell density (Carey et al. 1996), and canal function as manifested by the return of horizontal VOR gain (Carey et al. 1996; present results).

\section{ACKNOWLEDGMENTS}

This research was supported by NIH grants NS27050 (RB), DC01837 (RB and SMH) and DC02854 (EW Rubel). We thank Pat Keller for her histology assistance, Dr. Robert Baker for assistance in the preparation of some of the photomicrographs, Drs. Richard Rabbitt, Peter Steyger, and David Dickman for reviewing an earlier version of the manuscript, and NASA's Fundamental Biology.

\section{REFERENCES}

Ades HW, ENGSTRÖM H. Form and innervation of the vestibular epithelia. In: The Role of the Vestibular Organs in the Exploration of Space. NASA SP-77 Pensacola, FL, NASA, Washington DC, 1965, p. 23-41.

AdLer HJ, Poje CP, SAunders JC. Recovery of auditory function and structure in the chick after two intense pure tone exposures. Hear. Res. 71:214-224, 1993.

BAIRD RA, STEYGER PS, SCHUFF NR. Mitotic and nonmitotic hair cell regeneration in the bullfrog vestibular otolith organs. Ann NY Acad Sci 781:59-70, 1996.

Blumberg KR, Kevetter GA, Correia MJ. Reinnervation of regenerating hair cells in the avian crista ampullaris. Assoc. Res. Otolaryngol. Abstr. 19:381, 1997.

Boyle R, Carey JP, Highstein SM. Morphological correlates of response dynamics and efferent stimulation in horizontal semicircular canal afferents of the toadfish, Opsanus tau. J. Neurophysiol. 66:1504-1521, 1991.

Boyle R, Carey JP, Highstein SM, Rubel EW, Rabbitt RD. Recovery of anterior canal afferent spontaneous activity and responses to mechanical stimulation following aminoglycoside-induced hair cell loss in chicks. Soc. Neurosci. Abstr. 20:1191, 1994.

CAREY JP, FUCHS AF, RUBEL EW. Hair cell regeneration and recovery of the vestibuloocular reflex in the avian vestibular system. J. Neurophysiol. 76:3301-3312, 1996.

Boyle R, Highstein SM. In vivo and in vitro responses of horizontal semicircular canal afferents to rotatory and mechanical stimulation. Biol. Bull. 181:319, 1991.

Chen L, Trautwein PG, Shero M, Salvi RJ. Tuning, spontaneous activity and tonotopic map in chicken cochlear ganglion neurons following sound-induced hair cell loss and regeneration. Hear. Res. 98:152-164, 1966, DOI: 10.1016/0378-5955(96)00086-X.

CORWIN JT, COTANCHE DA. Regeneration of sensory hair cells after acoustic trauma. Science 240:1772-1774, 1988.

COTANCHE DA. Regeneration of hair cell stereociliary bundles in the chick cochlea following severe acoustic trauma. Hear. Res. 30:181-195, 1987a.

COTANCHE DA. Regeneration of tectorial membrane in the chick cochlea following severe acoustic trauma. Hear. Res. 30:197206, 1987b.

Cotanche DA, LeE KH, Stone JS, PICARd DA. Hair cell regeneration in the bird cochlea following noise damage or ototoxic drug damage. Anat. Embryol. 189:1-18, 1994.

Cruz RM, LAMbert PR, Rubel EW. Light microscopic evidence of hair cell regeneration after gentamycin toxicity in chick cochlea. Arch. Otolaryngol. Head Neck Surg. 113:1058-1062, 1987. 
DICKMAN JD, CORREIA MJ. Responses of pigeon horizontal semicircular canal afferent fibers. I. Step, trapezoid, and low-frequency sinusoid mechanical and rotational stimulation. J. Neurophysiol. 62:1090-1101, 1989a.

DICKMAN JD, CORREIA MJ. Responses of pigeon horizontal semicircular canal afferent fibers. High-frequency mechanical stimulation. J. Neurophysiol. 62:1102-1112, 1989b.

Dickman JD, Reder PA, Correia MJ. A method for controlled mechanical stimulation of single semicircular canals. J. Neurosci. Meth. 25:111-119, 1988.

Duckert LG, Rubel EW. Morphological correlates of functional recovery in the chick inner ear after gentamycin treatment. J. Comp. Neurol. 331:75-96, 1993.

FAVRE D, SANS A. Embryonic and postnatal development of afferent innervation in cat vestibular receptors. Acta Otolaryngol. 87:97107, 1979a.

FAVRE D, SANS A. Morphological changes in afferents vestibular hair cells synapses during the postnatal development in cat. J. Neurocytol. 8:765-775, 1979b.

FERNÁNDEZ C, BAIRd RA, GOLDBERG JM. The vestibular nerve of the chinchilla. I. Peripheral innervation patterns in the horizontal and superior semicircular canals. J. Neurophysiol. 60:167-181, 1988.

Fernández C, Lysakowski A, Goldberg JM. Hair-cell counts and afferent innervation patterns in the cristae ampullares of the squirrel monkey with comparison to the chinchilla. J. Neurophysiol. 73:1253-1269, 1995.

Goldberg JM, Smith CE, Fernández C. Relation between discharge regularity and responses to externally applied galvanic current in vestibular nerve afferents of the squirrel monkey. J. Neurophysiol. 51:1236-1256, 1984.

Goode CT, Carey JP, Fuchs AF, Rubel EW. Recovery of the vestibulocolic reflex after aminoglycoside ototoxicity in domestic chickens. J. Neurophysiol. 81:1025-1035, 1999.

HACKNey CM, Furness DN, SteYger PS. Structural abnormalities in inner hair cells following kanamycin-induced outer hair cell loss. In: Dallos P, Geisler CD, Matthews JW, Ruggero MA, Steele CR, (eds) The Mechanics and Biophysics of Hearing. SpringerVerlag New York, 1990, p. 10-17.

Henning AK, Cotanche DA. Regeneration of cochlear efferent nerve terminals after gentamycin damage. J. Neurosci. 18:32823296, 1998.

IgARASHI M, YoshinOBU T. Comparative observations on the eminentia cruciata in birds and mammals. Anat. Rec. 155:269-277, 1966.

JONES TA, NELSON RC. Recovery of vestibular function following hair cell destruction by streptomycin. Hear. Res. 62:181-186, 1992.

JoRgENSEN JM, MATHIESEN C. The avian inner ear. Continuous production of hair cells in vestibular sensory organs, but not in the auditory papilla. Naturwissenschaften 75:319-320, 1988.

KIL J, WARCHOL ME, CORWIN JT. Cell death, cell proliferation, and estimates of hair cell life spans in the vestibular organs of chicks. Hear. Res. 114:117-126, 1997, DOI: 10.1016/S0378-5955(97) 00166-4.

Lahaye J, Cordiez E. Die Belgische Reisetaube. La Paloma Hamburg, 1965.

LI W, CORREIA MJ. Recovery of semicircular canal primary afferent activity in the pigeon after streptomycin ototoxicity. J. Neurophysiol. 80:3297-3311, 1998.

LIPPE WR, WESTBROOK EW, RyALs BM. Hair cell regeneration in the chicken cochlea following aminoglycoside toxicity. Hear. Res. 56:203-210, 1991.

Lopez I, Honrubia V, Lee SC, Schoeman G, Beykirch K. Quantitation of the process of hair cell loss and recovery in the chinchilla crista ampullaris after gentamicin treatment. Int. J. Dev. Neurosci. 15:447-461, 1997, DOI: 10.1016/S0736-5748(96)00103-7.
LYSAKOWSKI A, GOLDBERG JM. A regional ultrastructural analysis of the cellular and synaptic architecture in the chinchilla cristae ampullares. J. Comp. Neurol. 389:419-443, 1997, DOI: 10.1002/ (SICI) 1096-9861 (19971222) 389:3<419::AID-CNE5 > 3.3.CO;2-Q.

Lysakowski A, Minor LB, Fernández C, Goldberg JM. Physiological identification of morphologically distinct afferent classes innervating the cristae ampullares of the squirrel monkey. J. Neurophysiol. 73:1270-1281, 1995.

MASETTO S, CORREIA MJ. Ionic currents in regenerating avian vestibular hair cells. Int. J. Dev. Neurosci. 15:387-399, 1997a, DOI: 10.1016/S0736-5748(96)00099-8.

MasetTo S, Correia MJ. Electrophysiological properties of vestibular sensory and supporting cells in the labyrinth slice: before and during regeneration. J. Neurophysiol. 78:1913-1927, 1997b.

MÜller M, Smolders JWT, Ding-PfennigdorfF D, Klinke R. Regeneration after tall hair cell damage following severe acoustic trauma in adult pigeons: correlation between cochlear morphology, compound action potential responses and single fiber properties in single animals. Hear. Res. 102:133-154, 1996, DOI: 10.1016/S0378-5955(96) 00155-4.

NiEMIEC AJ, RAPHAEL Y, MoODY DB. Return of auditory function following structural regeneration after acoustic trauma: behavioral measures from quail. Hear. Res. 75:209-224, 1994.

Poje CP, SeWELl DA, SAUNDERS JC. The effects of exposure to intense sound on the DC endocochlear potential in the chick. Hear. Res. 82:197-204, 1995, DOI: 10.1016/0378-5955(94)00177-R.

RabBitT RD, Boyle R, Highstein SM. Mechanical indentation of the vestibular labyrinth and its relationship to head rotation in the toadfish, Opsanus tau. J. Neurophysiol. 73:2237-2260, 1995.

RaPHAel Y, AdLer HJ, WANG Y, Finger PA. Cell cycle of transdifferentiating supporting cells in the basilar papilla. Hear. Res. 80:5363, 1994

Roberson DW, KREIG CS, RUBEL EW. Light microscopic evidence that direct transdifferentiation gives rise to new hair cells in regenerating avian auditory epithelium. Aud. Neurosci. 2:195-205, 1996.

Roberson DW, Weisleder P, Bohrer PS, Rubel EW. Ongoing production of sensory cells in the vestibular epithelium of the chick. Hear. Res. 57:166-174, 1992.

Rubel EW, Oesterle EC, Weisleder P. Hair cell regeneration in the avian inner ear. In: Bock GR, Whelan J, (eds) Regeneration of Vertebrate Sensory Receptor Cells. Wiley New York, 1991, p. 77-96.

Ryals BM, Rubel EW. Hair cell regeneration after acoustic trauma in adult Coturnix quail. Science 240:1774-1776, 1988.

RYALS BM, WESTBROOK EW. TEM analysis of neural terminals on autoradiographically identified regenerated hair cells. Hear. Res. 72:81-88, 1994.

Salvi RJ, Saunders SS, Hashino E, Chen L. Discharge patterns of chicken cochlear ganglion neurons following kanamycin-induced hair cell loss and regeneration. J. Comp. Neurol. 174:351-369, 1994.

SMITH CA. Inner Ear. In: KING AS, McLelland J, (eds) Form and Function in Birds Academic Press London, 1985, Vol. 3, p. 273-310.

SOKOLOwski BH, STAHL LM, Fuchs PA. Morphological and physiological development of vestibular hair cells in the organ-cultured otocyst of the chick. Dev. Biol. 155:134-146, 1993, DOI: 10.1006/dbio.1993.1013.

Steyger PS, Burton M, HaWkins JR, SChuff NR, BAird RA. Calbindin and parvalbumin are early markers of non-mitotically regenerating hair cells in the bullfrog vestibular otolith organs. Int. J. Dev. Neurosci. 15:417-432, 1997, DOI: 10.1016/S07365748(96)00101-3.

WEISLEDER P, RUBEL EW. Hair cell regeneration after streptomycin toxicity in the avian vestibular epithelium. J. Comp. Neurol. 331:97-110, 1993. 
Weisleder P, TSue TT, Rubel EW. Hair cell replacement in avian vestibular epithelium: supporting cell to Type I hair cell. Hear. Res. 82:125-133, 1995, DOI: 10.1016/0378-5955(94)00169-Q.

WERSÁLL J. Studies on the structure and innervation of the sensory epithelium of the cristae ampullaris in the guinea pig. A light and electron microscopic investigation. Acta Otolaryngol. Suppl. 126:1-85, 1956.

WERSÁLL J, BAGGER-SJÖÄCK D. Morphology of the vestibular sense organ. In: Kornhuber HH, (ed) Handbook of Sensory Physiology Springer-Verlag New York, Vol. VI/1, 1974, p. 123-170. 